\title{
Analysis of barriers to closed loop supply chain: A case of Indian automotive industry
}

\author{
Manjot Singh Bhatia \\ Jindal Global Business School, OP Jindal Global University, Sonipat, India \\ E-mail: manjotbht@gmail.com; manjotbht@iiml.ac.in \\ Suresh Jakhar \\ Indian Institute of Management, Lucknow, India \\ E-mail: skj@iiml.ac.in \\ Manoj Dora \\ Brunel Business School, Brunel University, UK \\ E-mail: manoj.dora@brunel.ac.uk
}

\begin{abstract}
Closed loop supply chain (CLSC) implementation has become imperative for organizations owing to resource scarcity and generation of toxic waste. However, CLSC implementation can be very challenging due to several barriers, especially in an emerging manufacturing hub such as India. This research identifies and analyzes the prominent barriers to CLSC implementation in the Indian automotive sector. Further, the paper also examines causal relationships between the barriers. A total of 22 barriers to CLSC implementation are identified from literature and subsequently, validated by industry experts. The finalized barriers are then evaluated by Analytical Hierarchy Process (AHP) and grey-Decision Making Trial and Evaluation Laboratory (DEMATEL) techniques. The study provides managers and policy makers with insights on the most prominent and causal barriers, and recommends strategies to overcome these barriers. The findings will help managers to frame short-term and long-term strategies to mitigate barriers to CLSC and contribute towards successful implementation of CLSC.
\end{abstract}

Keywords: Closed loop supply chain; barriers; AHP; grey - DEMATEL; India; automotive including reprinting/republishing this material for advertising or promotional purposes, creating new collective works, for resale or redistribution to servers or lists, or reuse of any copyrighted component of this work in other works. 
This article has been accepted for publication in a future issue of this journal, but has not been fully edited. Content may change prior to final publication. Citation information: DOI10.1109/TEM.2020.2998794, IEEE Transactions on Engineering Management

\section{Introduction}

During the last century, development of industry and technology together with the global trade has enormously increased economic growth, which has resulted in increase in the living standards of human beings (Kok et al., 2013). The current economy works on the basis of linear model ('take, make, waste'), wherein the resources that are transformed into products end up as waste after their first useful life (Dervojeda et al., 2014). Therefore, the linear model is highly unsustainable (Ellen MacArthur Foundation, 2013). Furthermore, developing countries such as India, China, etc. are rapidly catching up with the living standards of the developed nations. This development can be attributed to increasing resource usage. It is expected that the global resource usage will increase three times by the year 2050. To address these issues, there is a need to shift to the systems that are regenerative or restorative. The circular economy (CE) can act as a paradigm wherein the resources that are used for production enter an infinite loop of reuse, remanufacturing and recycling. Closed loop supply chain (CLSC) implementation can help to realize the objectives of $\mathrm{CE}$.

CLSC is "the design, control, and operation of a system to maximize value creation over the entire life cycle of a product with dynamic recovery of value from different types and volumes of returns over time" (Guide Jr. and Wassenhove, 2009). It has gained increased attention owing to environmental deterioration, customer awareness and government regulations (Pishvaee and Torabi, 2010; Ilgin and Gupta, 2010; Hong and Ke, 2011; Kenne et al., 2012; Govindan et al., 2015a; Özceylan and Paksoy, 2013). The focus of a CLSC is to recover value from the used products by integrating repair, reuse, refurbishing, remanufacturing and recycling operations (Thierry et al., 1995; Guide Jr. et al., 2003; Atasu et al., 2008; Metta and Badurdeen, 2013). 
This article has been accepted for publication in a future issue of this journal, but has not been fully edited. Content may change prior to final publication. Citation information: DOI10.1109/TEM.2020.2998794, IEEE Transactions on Engineering Management

Remanufacturing is the highest degree of product recovery method as it upgrades the used products to the quality standard of new products (Raz et al., 2017; Huang et al., 2019). It has been a prominent business in the United States and has also been lately implemented by the organizations in European nations due to its profitable nature and legislative regulations being imposed by the European Union (EU) (Östlin et al., 2008). Implementation of CLSC provides firms with economic, environmental and social benefits (Wang and Huang, 2013; Diabat et al., 2013; Dervojeda et al., 2014).

CLSC implementation is quite challenging as there are several barriers in its implementation (Dora et al., 2016). Few barriers to CLSC implementation include major upfront investments, dependency on suppliers and retailers for collaboration, current product designs which are based on linear model, lack of information exchange systems, etc. (Kok et al., 2013; Dervojeda et al., 2014). In our knowledge, there has not yet been any study that has considered the comprehensive list of barriers to CLSC implementation and evaluated the most prominent barriers, and causal relationships between the barriers. We fill this gap in literature and analyze the prominent barriers by Analytical Hierarchy Process (AHP), and causal relationships between the barriers by Decision Making Trial and Evaluation Laboratory (DEMATEL) technique. AHP considers barriers to be independent of each other while DEMATEL considers inter-relationships among the barriers. Thus, AHP is used to prioritize the barriers and DEMATEL is used for examining the inter-relationships between the barriers. Further, to consider uncertainty and vagueness associated with the expert judgements, grey-systems theory is integrated with DEMATEL (Bai and Sarkis, 2013). Hence, results obtained using the AHP can be used to formulate short term 
strategies, while findings obtained using grey DEMATEL can be used to frame long term strategies (Wu and Tsai, 2012; Mangla et al., 2016; Gandhi et al., 2016; Cui et al., 2019).

Indian automotive industry is currently fourth largest in the world and many firms are major exporters (IBEF, 2019). The sales of automobiles in domestic market witnessed an annual growth rate of $6.71 \%$ in the period between 2013 and 2019. Implementation of CE principles can help to keep several issues in check such as congestion, environmental pollution, greenhouse gas emissions, etc. There are several other benefits such as reduction of virgin materials, nonrenewable resources and energy. There will be a potential to extract over 8 million tons of steel from end of life (EOL) vehicles in 2025, which represents an economic opportunity of nearly 2.7 billion dollars. This makes the implementation of CLSC practices an important and appealing prospect for the Indian automobile manufacturing industry (Darbari et al., 2019). Thus, this study is done in Indian automotive industry. The findings provide managers with insights on the most prominent and causal barriers, and strategies that need to be adopted to overcome these barriers. As multi-method approach is used, the paper provides recommendations to overcome short term and long term barriers. The findings can be useful for organizations that are planning to implement CLSC or those in the early stages of CLSC implementation, specifically in emerging economies. In nutshell, the major contributions of this paper are:

1. Identification of barriers to CLSC implementation in the Indian automotive sector

2. Examining the prominent categories of barriers and sub-barriers to CLSC implementation

3. Analysis of cause and effect groups of barriers to CLSC implementation

4. Provide strategies to overcome barriers in short term and long term 
The remaining paper is structured as follows. Section 2 discusses the literature on CLSC and barriers to CLSC implementation. In Section 3, solution methodologies are discussed and in Section 4, an application is presented. Section 5 presents sensitivity analysis; Section 6 discusses managerial implications and Section 7 provides conclusions.

\section{Literature review}

\subsection{CLSC implementation}

The issues of resource scarcity and protection of environment have gained increased consideration throughout the world. The major issues involve how to minimize the generation of hazardous waste, prevent deterioration of environment caused by the generation of hazardous waste and recover valuable materials from the used products (Kannan et al., 2010). Products can be returned due to a number of reasons over the lifecycle, and can be classified as returns during the product lifecycle, end of use and EOL. CLSC implementation is viewed as an approach to achieve sustainable supply chain operations (Olugu and Wong, 2012), and resolve the above mentioned issues. CLSC management incorporates numerous strategies which aim to achieve greater efficiency (Geng et al., 2012).

The organizations have been focusing on zero waste management until now through the implementation of recycling processes (Dervojeda et al., 2014). However, reuse, repair, and remanufacturing activities can add most value. Examples of recovered products include automotive and electronics products, as these include high recoverable value as compared to other products (Easwaran and Üster, 2010). Few organizations that embrace the product recovery practices include Xerox, GM, Dell, HP, etc. However, product returns are of increasing concern 
This article has been accepted for publication in a future issue of this journal, but has not been fully edited. Content may change prior to final publication. Citation information: DOI10.1109/TEM.2020.2998794, IEEE Transactions on Engineering Management

to industries and many industries do not view activities associated to product returns as favorable. Presently, only the small percentage of the value from used products is being recovered by the organizations around the world (Atasu et al., 2008).

CLSC implementation can help to achieve economic and environmental benefits (Savaskan et al., 2004; Krikke et al., 2003). From the economic perspective, it helps to increase revenue, reduce production costs, lower buying costs for raw materials, etc. (Savaskan et al., 2004; Lee et al., 2009; Kadambala et al., 2017). CLSC implementation also provides firms with environmental benefits such as reduction in waste, virgin material usage, etc. (Garg et al., 2015; Jayaraman, 2006). Finally, CLSC implementation has some indirect benefits such as lesser sensitivity to price volatility, better relationship with the customers, creation of new jobs, etc. (Kok et al., 2013).

\subsection{Barriers to CLSC implementation}

Few authors have discussed about the potential barriers to CLSC implementation. Kok et al. (2013) discussed financial, institutional, infrastructural, societal and technological barriers to CE and provided few recommendations on steps that need to be taken. A survey conducted in the EU countries found 'Cultural barriers' to be the main barriers towards CE (Kirchherr et al., 2018). According to Dervojeda et al. (2014), major upfront investments and tendency of society for linear model are significant obstacles to CLSC implementation. Rizos et al. (2015) also cited upfront costs of implementation of green initiatives as significant barrier to CLSC implementation. 
This article has been accepted for publication in a future issue of this journal, but has not been fully edited. Content may change prior to final publication. Citation information: DOI10.1109/TEM.2020.2998794, IEEE Transactions on Engineering Management

Govindan and Hasanagic (2018) classified 39 barriers to CLSC implementation into following eight clusters: "Governmental issues", "Economic issues", "Technological issues", "Knowledge and skill issues", "Management issues", "Circular economy framework issues", "Cultural and social issues" and "Market issues". According to their review, the barriers that have been most discussed in literature include customer perception towards remanufactured products, lack of awareness about CE and technological limitations of firms to make remanufactured products. Mangla et al. (2018) examined 16 barriers to CLSC implementation by Interpretive Structural Modelling (ISM). The findings indicate "lack of environmental laws and regulations" and "lack of preferential tax policies for promoting the circular models" to be the major barriers. This study considers 22 barriers to implementation of CLSC. The barriers are classified as 'Financial', 'Technological', 'Cultural', 'Managerial' and 'Regulatory' barriers. The list of barriers examined in this study is given in Table 1 . The contribution of our study in comparison to other studies is also given in Table 2 .

Table 1. Barriers to CLSC implementation

\begin{tabular}{|c|c|c|c|}
\hline Category & Barrier & Description & References \\
\hline \multirow[t]{4}{*}{ Financial } & $\begin{array}{l}\text { High cost of transition from } \\
\text { linear to CLSC }\end{array}$ & $\begin{array}{l}\text { Costs of planning, R\&D, } \\
\text { infrastructure etc. }\end{array}$ & $\begin{array}{c}\text { World Economic Forum } \\
(2018)\end{array}$ \\
\hline & $\begin{array}{l}\text { Major upfront investment } \\
\text { required for CLSC } \\
\text { implementation }\end{array}$ & $\begin{array}{l}\text { Upfront fixed investments that } \\
\text { yield returns over a long term }\end{array}$ & $\begin{array}{c}\text { Dervojeda et al. (2014), } \\
\text { Rademaekers et al. } \\
(2011) \\
\end{array}$ \\
\hline & Limited access to funding & $\begin{array}{l}\text { Financial institutions are uncertain } \\
\text { about returns on circular models, } \\
\text { hence there is lack of funding }\end{array}$ & $\begin{array}{l}\text { Dervojeda et al. (2014), } \\
\text { Rizos et al. (2015) }\end{array}$ \\
\hline & $\begin{array}{l}\text { Total cost of products made } \\
\text { from recycled materials is } \\
\text { often higher }\end{array}$ & $\begin{array}{l}\text { Due to collection costs and low } \\
\text { recyclate quality, recycled } \\
\text { materials are often costly than } \\
\text { virgin materials }\end{array}$ & $\begin{array}{c}\text { Kok et al. (2013), } \\
\text { Kirchherr et al. (2018) }\end{array}$ \\
\hline \multirow[t]{2}{*}{ Technological } & $\begin{array}{l}\text { Low quality of } \\
\text { remanufactured products }\end{array}$ & $\begin{array}{l}\text { It is challenging to match the } \\
\text { quality of products that are } \\
\text { manufactured using recovered } \\
\text { materials }\end{array}$ & $\begin{array}{l}\text { Kirchherr et al. (2018), } \\
\text { Ghisellini et al. (2016) }\end{array}$ \\
\hline & $\begin{array}{l}\text { Design challenges of } \\
\text { products for reuse and } \\
\text { recovery }\end{array}$ & $\begin{array}{c}\text { It is challenging to design products } \\
\text { for reuse, disassembly and } \\
\text { remanufacturing }\end{array}$ & Ghisellini et al. (2016) \\
\hline
\end{tabular}




\begin{tabular}{|c|c|c|c|}
\hline & $\begin{array}{l}\text { Lack of metrics to measure } \\
\text { extent of circulatory }\end{array}$ & $\begin{array}{l}\text { There are lack of standardized } \\
\text { metrics by which progress can be } \\
\text { measured }\end{array}$ & $\begin{array}{l}\text { World Economic Forum } \\
\text { (2018) }\end{array}$ \\
\hline & $\begin{array}{l}\text { Lack of information } \\
\text { exchange }\end{array}$ & $\begin{array}{l}\text { Lack of information systems } \\
\text { hinders exchange of materials }\end{array}$ & $\begin{array}{c}\text { Kok et al. (2013), Rizos } \\
\text { et al. (2015) }\end{array}$ \\
\hline & $\begin{array}{l}\text { Limited availability and } \\
\text { quality of recycling material }\end{array}$ & $\begin{array}{l}\text { There are limited number of used } \\
\text { products available and available } \\
\text { used products are of low quality }\end{array}$ & Kok et al. (2013) \\
\hline & $\begin{array}{l}\text { Challenges involved in } \\
\text { separation of bio-material } \\
\text { from techno-cycle }\end{array}$ & $\begin{array}{l}\text { The changes that aim at circular } \\
\text { economy } \\
\text { can lead to challenges for } \\
\text { separation of materials that belong } \\
\text { to bio-cycle from those belonging } \\
\text { in the techno-cycle }\end{array}$ & $\begin{array}{l}\text { Kok et al. (2013), } \\
\text { Ghisellini et al. (2016), } \\
\text { Mishra et al. (2018) }\end{array}$ \\
\hline \multirow[t]{3}{*}{ Cultural } & Lack of awareness & $\begin{array}{l}\text { The awareness of people on } \\
\text { significance of the CLSC is limited }\end{array}$ & Kok et al. (2013) \\
\hline & Resistance to change & $\begin{array}{l}\text { The current way of thinking } \\
\text { inhibits shift towards CE }\end{array}$ & $\begin{array}{l}\text { Dervojeda et al. (2014), } \\
\quad \text { Rizos et al. (2015) }\end{array}$ \\
\hline & $\begin{array}{l}\text { Perception of customers } \\
\text { towards quality of reused } \\
\text { materials }\end{array}$ & $\begin{array}{l}\text { Customers generally have } \\
\text { perception that refurbished } \\
\text { products are not of good quality }\end{array}$ & $\begin{array}{l}\text { Genovese et al. (2015), } \\
\text { Weelden et al. (2016) }\end{array}$ \\
\hline \multirow[t]{4}{*}{ Regulatory } & $\begin{array}{c}\text { Recycling policies in waste } \\
\text { management are ineffective } \\
\text { to obtain high quality } \\
\text { recycling }\end{array}$ & $\begin{array}{l}\text { Recycling policies do not support } \\
\text { high quality recycling }\end{array}$ & $\begin{array}{l}\text { Kok et al. (2013), de } \\
\text { Man and Friege (2016) }\end{array}$ \\
\hline & $\begin{array}{l}\text { Current laws in waste } \\
\text { management do not support } \\
\text { CLSC implementation }\end{array}$ & $\begin{array}{l}\text { The current laws related to } \\
\text { environment in some economies do } \\
\text { not support CLSC implementation }\end{array}$ & $\begin{array}{l}\text { Li and } \mathrm{Yu}(2011), \text { Kok } \\
\text { et al. (2013), Rizos et al. } \\
\text { (2015) }\end{array}$ \\
\hline & $\begin{array}{l}\text { Complicated or inflexible } \\
\text { regulatory structures }\end{array}$ & $\begin{array}{l}\text { Policies and regulations were } \\
\text { designed according to linear } \\
\text { process and limit innovation in CE }\end{array}$ & $\begin{array}{l}\text { World Economic Forum } \\
\text { (2018) }\end{array}$ \\
\hline & $\begin{array}{c}\text { Financial governmental } \\
\text { incentives support linear } \\
\text { economy }\end{array}$ & $\begin{array}{c}\text { The financial governmental } \\
\text { incentives such as value added tax } \\
\text { stimulate high material } \\
\text { consumption above service, } \\
\text { because labor is highly } \\
\text { taxed, leaving materials relatively } \\
\text { cheap. }\end{array}$ & Kok et al. (2013) \\
\hline \multirow[t]{5}{*}{ Managerial } & $\begin{array}{c}\text { Poor leadership and } \\
\text { management towards } \\
\text { implementation of CLSC }\end{array}$ & $\begin{array}{l}\text { There is lack of interest to } \\
\text { implement CLSC due to poor } \\
\text { leadership and management }\end{array}$ & $\begin{array}{l}\text { Shahbazi et al. (2016), } \\
\text { Su et al. (2013) }\end{array}$ \\
\hline & $\begin{array}{l}\text { More priority to other issues } \\
\text { in supply chain }\end{array}$ & $\begin{array}{c}\text { Managers give more priority to } \\
\text { other issue - e.g. expansion of } \\
\text { market share }\end{array}$ & $\begin{array}{l}\text { Shahbazi et al. (2016), } \\
\text { Govindan and Hasanagic } \\
\text { (2018) }\end{array}$ \\
\hline & $\begin{array}{l}\text { Organizational structure } \\
\text { makes it challenging to } \\
\text { implement CLSC }\end{array}$ & $\begin{array}{l}\text { Organizational structures - e.g. } \\
\text { inefficient bureaucracy act as a } \\
\text { challenge }\end{array}$ & Liu and Bai (2014) \\
\hline & $\begin{array}{l}\text { No inventive schemes for } \\
\text { managers to use recycled } \\
\text { materials }\end{array}$ & $\begin{array}{l}\text { Managers don't get incentives for } \\
\text { taking initiatives towards } \\
\text { implementation of CLSC }\end{array}$ & Kok et al. (2013) \\
\hline & $\begin{array}{l}\text { Lack of appropriate skills in } \\
\text { personnel }\end{array}$ & $\begin{array}{l}\text { The employees in organizations do } \\
\text { not possess skills required for } \\
\text { CLSC implementation }\end{array}$ & $\begin{array}{l}\text { Liu and Bai (2014); } \\
\text { Weelden et al. (2016); } \\
\text { Rizos et al. (2015) }\end{array}$ \\
\hline
\end{tabular}


This article has been accepted for publication in a future issue of this journal, but has not been fully edited. Content may change prior to final publication. Citation information: DOI10.1109/TEM.2020.2998794, IEEE Transactions on Engineering Management

Table 2. Comparative studies on CLSC barriers

\begin{tabular}{|l|l|c|c|}
\hline Study & \multicolumn{1}{|c|}{ Description } & Country & Methodology \\
\hline Kok et al. (2013) & Discussion of obstacles to CE & Netherlands & Interviews \\
\hline Dervojeda et al. (2014) & Identification of barriers to CLSC & Multiple & Case studies \\
\hline Rizos et al. (2015) & Identification of barriers to CE & - & Review \\
\hline Wei et al. (2015) & Barriers to remanufacturing in CLSC & China & Survey \\
\hline Zhang et al. (2017) & Barriers to remanufacturing in CLSC & China & Case studies \\
\hline Kirchherr et al. (2018) & Analysis of barriers to CE & Europe & Survey \\
\hline Mangla et al. (2018) & $\begin{array}{l}\text { Identification of contextual interactions } \\
\text { among barriers to CLSC }\end{array}$ & India & ISM \\
\hline Govindan and Hasanagic (2018) & Classification of barriers to CLSC & - & $\begin{array}{c}\text { Systematic } \\
\text { review }\end{array}$ \\
\hline Our study & $\begin{array}{l}\text { Examine prominent barriers, and cause and } \\
\text { effect groups of barriers }\end{array}$ & $\begin{array}{l}\text { India } \\
\text { AHP and grey- } \\
\text { DEMATEL }\end{array}$ \\
\hline
\end{tabular}

\subsection{Research objectives}

India is currently the second largest populated country, and accounts for nearly $18 \%$ of the world's population. It is experiencing several deterioration of environment as 14 out of the 15 world's most polluted cities are from India, according to the recent report by the World Health Organization (WHO). On one side, there is a quest to maintain the industrial growth to become a fully developed economy but there is also a need to identify the business models that do not aggravate the resource constraints. CLSC implementation can help to achieve the same as it decouples growth and resource requirements (Ellen MacArthur Foundation, 2016). Through the implementation of CE models, India has nearly half a trillion dollars' worth of economic potential that can be unlocked by the year 2030. Suitable management of plastics waste can create over 14 lakh jobs, a potential opportunity of 2 billion dollars (FICCI, 2018).

A review of the existing literature indicates that research in barriers to CLSC implementation is relatively scant. Recently, Mangla et al. (2018) analyzed barriers to CLSC implementation using the ISM. Firstly, the study considered limited barriers. Further, the authors' applied ISM that finds inter-relationships among the barriers but neither quantifies nor ranks the barriers 
This article has been accepted for publication in a future issue of this journal, but has not been fully edited. Content may change prior to final publication. Citation information: DOI10.1109/TEM.2020.2998794, IEEE Transactions on Engineering Management

(Mathiyazhagan et al., 2014). Also, ISM does not classify the barriers into cause and effect groups. Thus, there is a need for a comprehensive study that takes into consideration all the barriers and further, quantifies, ranks and categorizes the barriers into cause and effect groups. The ranking of barriers is useful to devise short term strategies, and causal relationships will help firms to formulate long term strategies (Mangla et al., 2016). In the view of the above discussion, this study has following objectives:

RQ1: What are the barriers to CLSC implementation in Indian automotive sector?

RQ2: What is the framework that should be used for the evaluation of barriers to CLSC?

RQ3: What are the prominent categories of barriers and sub-barriers to CLSC implementation? RQ4: What are cause and effect relationships between the barriers to implementation of CLSC?

\section{Solution methodology}

In real life situations, people are supposed to make decisions in an environment in which there are conflicting criteria (Gölcük and Baykasoğlu, 2016). Multi-criteria decision making (MCDM) methods are commonly used in such situations (Dwivedi et al., 2018). In this study, AHP (Saaty, 1980) is used to evaluate the importance of barriers to CLSC implementation. Grey - DEMATEL is used to divide the barriers into cause and effect groups, and establish contextual relationships between the barriers (Luthra et al., 2018). ISM has also been used for developing structural models and find inter-relationships among barriers in several fields. However, as the number of variables or factors are increased, ISM becomes complex to apply and hence only a limited number of factors can be considered in developing an ISM model (Govindan et al., 2014). Further, ISM neither ranks the variables nor quantifies the variables (Mudgal et al., 2010). Analytic network process (ANP) can also be used, however it requires a very complex survey 
This article has been accepted for publication in a future issue of this journal, but has not been fully edited. Content may change prior to final publication. Citation information: DOI10.1109/TEM.2020.2998794, IEEE Transactions on Engineering Management

procedure for non-expert's viewpoint (Harputlugil et al., 2011). Technique for Order Preference by Similarity to Ideal Solution (TOPSIS) is used for evaluating the best choice from available alternatives (Dwivedi et al., 2018). Hence, TOPSIS is not an appropriate method for this study

AHP is considered better than other MCDM methods as it easier to use and has wide applicability (Harputlugil et al., 2011). It is a well- known and widely used decision making tool in business organizations (Govindan et al., 2014; Mathew et al., 2020). AHP decomposes, organizes and analyzes the problem, and converts the problem into a hierarchical structure, which allows decision maker to pay attention on criterion and sub-criterion during the process of weight allocation (Ishizaka and Labib, 2011). AHP generates weight for each criterion according to pairwise comparisons done by the decision maker. The higher weight indicates more importance of the corresponding criteria. AHP also involves a process to check internal consistency of pairwise comparisons through the calculation of internal consistency ratio. Further, AHP does not requires large sample size for analysis (Rahman et al., 2019).

DEMATEL determines causal relationships between the factors taken into consideration in a study (Fontela and Gabus, 1974; Jeng and Huang, 2015; Gölcüka and Baykasoglu, 2016), which can help firms in making long term strategies. DEMATEL is one of the most widely used method for analyzing interdependencies among the factors (Gölcük and Baykasoğlu, 2016; Duman et al., 2019; Singh et al., 2019). The integration of grey systems theory accounts for vagueness and uncertainty in judgements made by experts (Deng, 1989; Singh and Misra, 2019). 
Many authors have applied AHP to analyze the barriers in other fields (Shi et al., 2008; Patil and Kant; 2014; Dang and Chu, 2016; Luthra et al., 2016; Bouzon et al., 2016; Yadav and Desai, 2017; Moktadir et al., 2019). Grey - DEMATEL has also been used to by a number of authors to analyze certain problems in many fields (Xia et al., 2015; Luthra et al., 2018; Bhatia et al., 2020). Hence, the combination of AHP and grey - DEMATEL is considered as an appropriate tool for achieving the aims of this study. In the next section, we discuss the formulation of the MCDM problem in detail. The MCDM techniques are also briefly described in Appendix 1 and Appendix 2.

\subsection{Formulation of MCDM problem}

\subsubsection{AHP method}

Firstly, a comparison matrix is created, involving comparison among the barriers / sub-barriers. An entry $a_{j k}$ in the matrix represents importance of $j^{\text {th }}$ barrier relative to $k^{\text {th }}$ barrier. The barriers are compared using the Saaty's scale given in Table 3.

$$
\mathrm{A}=\left[\begin{array}{ccccccc}
a_{11} & a_{12} & a_{13} & \cdots & \cdots & a_{1(n-1)} & a_{1 n} \\
a_{21} & a_{22} & a_{23} & \cdots & \cdots & a_{2(n-1)} & a_{2 n} \\
\cdots & \cdots & \cdots & \cdots & \cdots & \cdots & \cdots \\
\cdots & \cdots & \cdots & \cdots & \cdots & \cdots & \cdots \\
\cdots & \cdots & \cdots & \cdots & \cdots & \cdots & \cdots \\
a_{(n-1) 1} & a_{(n-1) 2} & a_{(n-1) 3} & d_{(n-1) 4} & \cdots & 0 & a_{(n-1) n} \\
a_{n 1} & a_{n 2} & \cdots & \cdots & \cdots & a_{n(n-1)} & a_{n n}
\end{array}\right]
$$

Table 3. Scale of preference (Saaty, 1980)

\begin{tabular}{|l|c|c|c|c|c|c|}
\hline Preference weight & 1 & 3 & 5 & 7 & 9 & $2,4,6,8$ \\
\hline Judgement & $\begin{array}{c}\text { Equally } \\
\text { important }\end{array}$ & $\begin{array}{c}\text { Moderately } \\
\text { important }\end{array}$ & $\begin{array}{c}\text { Strongly } \\
\text { important }\end{array}$ & $\begin{array}{c}\text { Very strongly } \\
\text { important }\end{array}$ & $\begin{array}{c}\text { Extremely } \\
\text { important }\end{array}$ & $\begin{array}{c}\text { Intermediate } \\
\text { values }\end{array}$ \\
\hline
\end{tabular}

Then, normalized comparison matrix is calculated, where each entry $\bar{a}_{j k}$ is calculated by Eq. (1)

$$
\bar{a}_{j k}=\frac{a_{j k}}{\sum_{i=1}^{n} a_{j k}}
$$


The weights of each barrier / sub-barrier $\left(w_{j}\right)$ are then calculated by taking the average of entries in each row of normalized comparison matrix (Eq. 2)

$w_{j}=\frac{\sum_{i=1}^{n} \bar{a}_{j k}}{n}$

Finally, consistency ratio (CR) is evaluated for each set of pairwise comparison (Eq. 3)

$\mathrm{CR}=\mathrm{CI} / \mathrm{RI}$; CI: consistency index; RI: random index

$C I=\left(\lambda_{\max }-n\right) /(n-1) ; n$ : matrix of order $n ; \lambda_{\max }$ : Maximum eigenvalue

RI values for matrices of different orders are given in Table 4. Preferably, CR should be less than

0.1 (Madaan and Mangla, 2015).

Table 4. RI values for matrix of order $\mathrm{n}$

\begin{tabular}{|l|l|l|l|l|l|l|l|l|l|}
\hline $\mathrm{n}$ & 2 & 3 & 4 & 5 & 6 & 7 & 8 & 9 & 10 \\
\hline $\mathrm{RI}$ & 0 & 0.58 & 0.90 & 1.12 & 1.24 & 1.32 & 1.41 & 1.45 & 1.51 \\
\hline
\end{tabular}

\subsubsection{Grey-DEMATEL method}

Firstly, a direct influence matrix is obtained, representing influence among the barriers

$$
\mathrm{D}=\left[\begin{array}{ccccccc}
0 & d_{12} & d_{13} & \cdots & \cdots & d_{1(n-1)} & d_{1 n} \\
d_{21} & 0 & d_{23} & \cdots & \cdots & d_{2(n-1)} & d_{2 n} \\
\cdots & \cdots & \cdots & \cdots & \cdots & \cdots & \cdots \\
\cdots & \cdots & \cdots & \cdots & \cdots & \cdots & \cdots \\
\cdots & \cdots & \cdots & \cdots & \cdots & \cdots & \cdots \\
d_{(n-1) 1} & d_{(n-1) 2} & d_{(n-1) 3} & d_{(n-1) 4} & \cdots & 0 & d_{(n-1) n} \\
d_{n 1} & d_{n 2} & \cdots & \cdots & \cdots & d_{n(n-1)} & 0
\end{array}\right]
$$

The matrix D is normalized using the CFCS (Converting fuzzy data into crisp scores) method explained below (Dou et al., 2014):

$\otimes A_{m n}^{k}$ : Grey number of expert k (Influence of factor $\mathrm{m}$ on factor $\left.\mathrm{n}\right)$

$\underline{\otimes} A_{m n}^{k}$ and $\bar{\otimes} A_{m n}^{k}$ : Lower and upper values of grey number $\otimes A_{m n}^{k}$, respectively.

The crisp values are calculated as:

$\underline{\otimes} \bar{A}_{\mathrm{mn}}^{\mathrm{k}}=\left(\underline{\otimes} A_{m n}^{k}-{ }_{n}^{\min } \unrhd A_{m n}^{k}\right) / \Delta_{m i n}^{\max }$ 
$\bar{\circledast} \bar{A}_{\mathrm{mn}}^{\mathrm{k}}=\left(\bar{\otimes} A_{m n}^{k}-\min _{n} \bar{\otimes} A_{m n}^{k}\right) / \Delta_{\min }^{\max }$

where, $\Delta_{\min }^{\max }=\max _{n} \circledast A_{m n}^{k}-{ }_{n}^{\min } \circledast A_{m n}^{k}$

The total normalized crisp value and final crisp values are calculated as:

$$
\begin{aligned}
& B_{m n}^{k}=\frac{\left(\unrhd \bar{A}_{\mathrm{mn}}{ }^{\mathrm{k}}\left(1-\underline{\otimes} \bar{A}_{\mathrm{mn}}{ }^{\mathrm{k}}\right)+\left(\bar{\otimes} \bar{A}_{\mathrm{mn}}{ }^{\mathrm{k}} * \bar{\otimes} \bar{A}_{\mathrm{mn}}{ }^{\mathrm{k}}\right)\right)}{\left(1-\underline{\otimes} \bar{A}_{\mathrm{mn}}{ }^{\mathrm{k}}+\bar{\otimes} \bar{A}_{\mathrm{mn}}{ }^{\mathrm{k}}\right)} \\
& C_{m n}^{k}={ }_{n}^{\min _{n} \otimes A_{m n}^{k}+B_{m n}^{k} \Delta_{m i n}^{\max }}
\end{aligned}
$$

The next step involves calculation of normalized direct-relation matrix " $\mathrm{N}$ "

"N" is computed using the Eq. (8) and Eq. (9).

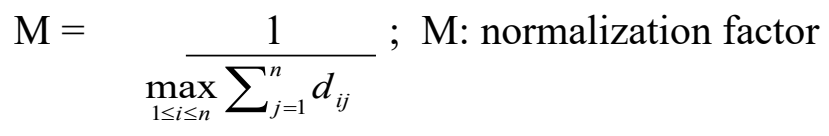

$\mathrm{N}=\mathrm{M} * \mathrm{D}$

Then, Total relation matrix " $T$ " is calculated using Eq. (10)

$\mathrm{T}=\mathrm{N}(\mathrm{I}-\mathrm{N})^{-1} ; \mathrm{I}$ : Identity matrix

The next step entails calculation of sum of rows and columns of " $\mathrm{T}$ "

$$
\begin{aligned}
& \mathrm{R}=\left[\sum_{j=1}^{j=n} m_{i j}\right]_{n \times 1} \text { (Sum of rows) } \\
& \mathrm{C}=\left[\sum_{i=1}^{i=n} m_{i j}\right]_{1 \times n}^{\prime} \quad \text { (Sum of columns) }
\end{aligned}
$$

Finally, causal diagram is plotted on graph using $\left(\mathrm{R}_{\mathrm{i}}+\mathrm{Ci}\right)$ (horizontal axis) and $\left(\mathrm{R}_{\mathrm{i}}-\mathrm{C}_{\mathrm{i}}\right)$ (vertical axis) values. 


\section{An Application}

This section demonstrates an application and analyze the barriers in Indian automotive sector.

The approach involves the four phases, discussed in the following sections. The outline of the approach is shown in Fig. 1.

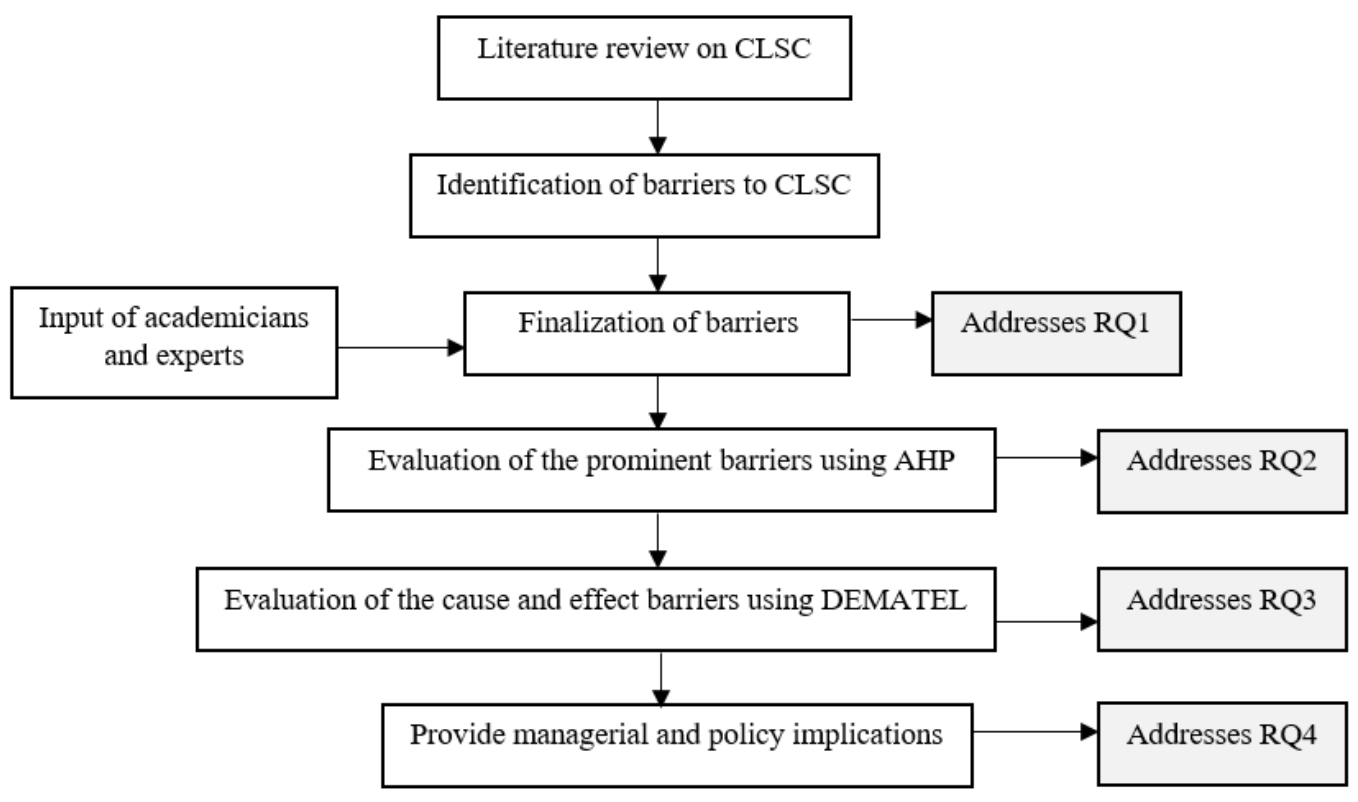

Fig. 1. Framework of this study

\subsection{Phase 1: Identification of barriers to CLSC}

Firstly, barriers to CLSC implementation are identified from literature review (Table 1). A total of 22 barriers are shortlisted and considered for validation from industry experts. The barriers are classified into the following five categories: Financial, technological, cultural, managerial and regulatory barriers. 
This article has been accepted for publication in a future issue of this journal, but has not been fully edited. Content may change prior to final publication. Citation information: DOI10.1109/TEM.2020.2998794, IEEE Transactions on Engineering Management

\subsection{Phase 2: Validation of barriers to CLSC implementation}

The barriers to CLSC shortlisted in phase 1 are validated by seven industry experts in Indian automotive sector. The profiles of experts are presented in Table 5. According to the inputs from experts, few barriers are eliminated in this phase. Finally, 17 barriers are considered for analysis in phase 3 and phase 4 . The finalized barriers considered for the analysis are shown in Table 6.

The hierarchical structure of barriers is shown in Fig. 2.

Table 5. Profile of industry experts

\begin{tabular}{|l|c|c|c|}
\hline & Department & Experience & Position \\
\hline Expert 1 & Purchasing & 9 years & Section Head \\
\hline Expert 2 & Purchasing & 8 years & Section Head \\
\hline Expert 3 & Costing & 19 years & Additional General Manager \\
\hline Expert 4 & Strategic sourcing & 13 years & Supply chain manager \\
\hline Expert 5 & Design and development & 11 years & Manager \\
\hline Expert 6 & Production Planning and control & 20 years & Deputy General Manager \\
\hline Expert 7 & Marketing and sales & 20 years & Vice President \\
\hline
\end{tabular}

Table 6. List of finalized barriers

\begin{tabular}{|l|c|l|}
\hline Category & Code & \\
\hline Financial (FN) & FN1 & High cost of transition from linear to CLSC \\
\hline & FN2 & Major upfront investment required for CLSC implementation \\
\hline & FN3 & Total cost of product made from recycled materials is often higher \\
\hline Technological (TC) & TC1 & Low quality of remanufactured products \\
\hline & TC2 & Limited availability and quality of recycling material \\
\hline & TC3 & Challenges involved in separation of bio-material from techno-cycle \\
\hline Cultural (CL) & CL1 & Lack of awareness \\
\hline & CL2 & Resistance to change \\
\hline & CL3 & Perception of customers towards quality of reused materials \\
\hline Regulatory (RL) & RL1 & Recycling policies in waste management are ineffective to obtain high quality recycling \\
\hline & RL2 & Current laws in waste management do not support CLSC implementation \\
\hline & RL3 & Complicated or inflexible regulatory structures \\
\hline & RL4 & Financial governmental incentives support the linear economy \\
\hline Managerial (MG) & MG1 & Poor leadership and management towards implementation of CLSC \\
\hline & MG2 & Higher priority of other issues in supply chain \\
\hline & MG3 & No inventive schemes for managers to use recycled materials \\
\hline & MG4 & Lack of appropriate skills in personnel \\
\hline & &
\end{tabular}




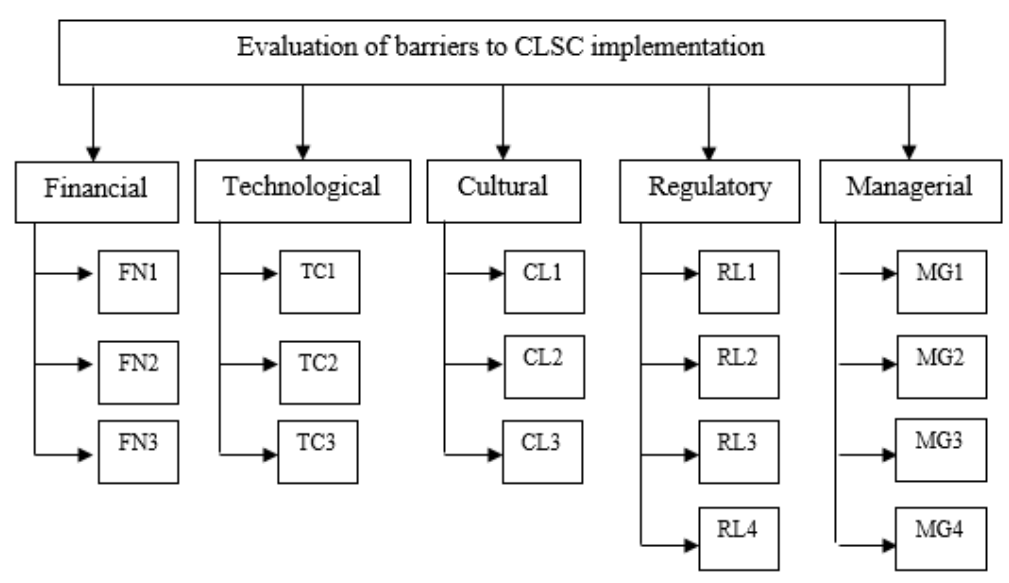

Fig. 2. Hierarchical structure of barriers

\subsection{Phase 3: Evaluation of barriers using AHP}

The barriers finalized in phase 2 are then evaluated using AHP. The relative importance of barriers is obtained using the input of industry experts. The pairwise comparisons between the barriers are done using the Saaty's scale (Appendix 3). The pairwise comparison matrices are given in Table 7. Table 8 presents overall ranking of barriers, which are based on global weights obtained using AHP.

Table 7. Pairwise comparison matrices

\begin{tabular}{|c|c|c|c|c|c|c|c|}
\hline \multicolumn{8}{|c|}{ Categories of barriers } \\
\hline Barriers & FN & TC & $\mathbf{C L}$ & $\mathbf{R L}$ & MG & Weight & Ranking \\
\hline FN & 1 & 0.2 & 0.5 & 0.25 & 0.166 & 0.048 & 5 \\
\hline TC & 5 & 1 & 0.166 & 0.143 & 0.111 & 0.061 & 4 \\
\hline CL & 2 & 6 & 1 & 0.5 & 0.333 & 0.166 & 3 \\
\hline RL & 4 & 7 & 2 & 1 & 1 & 0.323 & 2 \\
\hline MG & 6 & 9 & 3 & 1 & 1 & 0.400 & 1 \\
\hline \multicolumn{8}{|c|}{ Financial barriers } \\
\hline Barriers & \multicolumn{2}{|c|}{ FN1 } & FN2 & & FN3 & Weight & Ranking \\
\hline FN1 & \multicolumn{2}{|c|}{1} & \multicolumn{2}{|c|}{1} & 0.5 & 0.240 & 2 \\
\hline FN2 & \multicolumn{2}{|c|}{1} & \multicolumn{2}{|l|}{1} & 0.33 & 0.209 & 3 \\
\hline FN3 & \multicolumn{2}{|c|}{2} & \multicolumn{2}{|l|}{3} & 1 & 0.549 & 1 \\
\hline \multicolumn{8}{|c|}{ Technological barriers } \\
\hline Barriers & \multicolumn{2}{|c|}{ TC1 } & \multirow{2}{*}{\multicolumn{2}{|c|}{ TC2 }} & TC3 & Weight & Ranking \\
\hline TC1 & \multicolumn{2}{|c|}{1} & \multirow{2}{*}{\multicolumn{2}{|c|}{$\frac{0.25}{1}$}} & 0.2 & 0.093616 & 3 \\
\hline TC2 & & & & & 0.333 & 0.279688 & 2 \\
\hline
\end{tabular}




\begin{tabular}{|c|c|c|c|c|c|c|}
\hline TC3 & 5 & & 3 & 1 & 0.626696 & 1 \\
\hline \multicolumn{7}{|c|}{ Cultural and social barriers } \\
\hline Barriers & CL & & CL2 & CL3 & Weight & Ranking \\
\hline CL1 & 1 & & 1 & 1 & 0.32748 & 2 \\
\hline CL2 & 1 & & 1 & 0.5 & 0.259921 & 3 \\
\hline CL3 & 1 & & 2 & 1 & 0.412599 & 1 \\
\hline \multicolumn{7}{|c|}{ Regulatory barriers } \\
\hline Barriers & RL1 & RL2 & RL3 & RL4 & Weight & Ranking \\
\hline RL1 & 1 & 1 & 0.5 & 0.25 & 0.120539 & 4 \\
\hline RL2 & 1 & 1 & 1 & 0.333 & 0.154035 & 3 \\
\hline RL3 & 2 & 1 & 1 & 0.2 & 0.161219 & 2 \\
\hline RL4 & 4 & 3 & 5 & 1 & 0.564207 & 1 \\
\hline \multicolumn{7}{|c|}{ Managerial barriers } \\
\hline Barriers & MG1 & MG & MG3 & MG4 & Weight & Ranking \\
\hline MG1 & 1 & 0.2 & 0.166 & 1 & 0.083243 & 4 \\
\hline MG2 & 5 & 1 & 0.25 & 0.5 & 0.173221 & 3 \\
\hline MG3 & 6 & 4 & 1 & 3 & 0.567497 & 1 \\
\hline MG4 & 1 & 2 & 0.333 & 1 & 0.176039 & 2 \\
\hline
\end{tabular}

Table 8. Overall ranking of barriers

\begin{tabular}{|l|c|c|c|c|c|}
\hline Category & Relative weight & Sub-barriers & Relative weights & Global weight & Rank \\
\hline Financial & 0.04838 & FN1 & 0.240211 & 0.011621 & 15 \\
\hline & & FN2 & 0.209844 & 0.010152 & 16 \\
\hline & & FN3 & 0.549946 & 0.026606 & 13 \\
\hline Technological & 0.060954 & TC1 & 0.093616 & 0.005706 & 17 \\
\hline & & TC2 & 0.279688 & 0.017048 & 14 \\
\hline & & TC3 & 0.626696 & 0.0382 & 11 \\
\hline Cultural & 0.166308 & CL1 & 0.32748 & 0.054463 & 6 \\
\hline & & CL2 & 0.259921 & 0.043227 & 9 \\
\hline & & CL3 & 0.412599 & 0.068619 & 5 \\
\hline Regulatory & 0.323851 & RL1 & 0.120539 & 0.039037 & 10 \\
\hline & & RL2 & 0.154035 & 0.049884 & 8 \\
\hline & & RL3 & 0.161219 & 0.052211 & 7 \\
\hline & & RL4 & 0.564207 & 0.182719 & 2 \\
\hline Managerial & 0.400507 & MG1 & 0.083243 & 0.03334 & 12 \\
\hline & & MG2 & 0.173221 & 0.069376 & 4 \\
\hline & & MG3 & 0.567497 & 0.227287 & 1 \\
\hline & & MG4 & 0.176039 & 0.070505 & 3 \\
\hline
\end{tabular}

\subsection{Phase 4: Analysis of barriers using grey - DEMATEL}

Grey-DEMATEL is used for classifying the barriers into cause and effect groups. The input of three experts is considered for analysis. However, three experts are considered as sufficient for DEMATEL analysis. Many studies which have applied DEMATEL used responses from four or lesser number of experts (Zhu et al., 2014; Xia et al., 2015; Govindan et al., 2015b; Bhatia and 
Srivastava, 2018). The direct relation matrix of expert 1 is shown in Table 9. The comparison is done by experts using linguistic terms given in Appendix 3. The total relation matrix is given in Appendix 4 (Calculated by giving equal weights to all the experts). The prominence and cause / effect values of barriers are given in Table 10.

Table 9. Direct relation matrix (Expert 1)

\begin{tabular}{|c|c|c|c|c|c|c|c|c|c|c|c|c|c|c|c|c|c|}
\hline & FN1 & FN2 & FN3 & TC1 & TC2 & TC3 & CL1 & CL2 & CL3 & RL1 & RL2 & RL3 & RL4 & MG1 & MG2 & MG3 & MG4 \\
\hline FN1 & $\mathrm{N}$ & $\mathrm{H}$ & $\mathrm{H}$ & $\mathrm{L}$ & $\mathrm{H}$ & $\mathrm{VH}$ & $\mathrm{L}$ & $\mathrm{L}$ & $\mathrm{L}$ & $\mathrm{L}$ & $\mathrm{L}$ & VH & $\mathrm{VH}$ & $\mathrm{H}$ & $\mathrm{H}$ & $\mathrm{L}$ & $\mathrm{H}$ \\
\hline FN2 & $\mathrm{H}$ & $\mathrm{N}$ & $\mathrm{VH}$ & $\mathrm{VH}$ & $\mathrm{VH}$ & $\mathrm{H}$ & $\mathrm{VH}$ & $\mathrm{H}$ & $\mathrm{H}$ & $\mathrm{VH}$ & $\mathrm{H}$ & $\mathrm{H}$ & $\mathrm{VH}$ & $\mathrm{H}$ & $\mathrm{H}$ & $\mathrm{H}$ & $\mathrm{H}$ \\
\hline FN3 & $\mathrm{H}$ & $\mathrm{VH}$ & $\mathrm{N}$ & $\mathrm{H}$ & $\mathrm{VH}$ & $\mathrm{H}$ & $\mathrm{H}$ & $\mathrm{VH}$ & $\mathrm{H}$ & $\mathrm{L}$ & $\mathrm{H}$ & $\mathrm{H}$ & $\mathrm{H}$ & $\mathrm{VH}$ & $\mathrm{VH}$ & $\mathrm{H}$ & $\mathrm{L}$ \\
\hline TC1 & $\mathrm{H}$ & $\mathrm{H}$ & $\mathrm{VH}$ & $\mathrm{N}$ & $\mathrm{H}$ & $\mathrm{H}$ & $\mathrm{H}$ & $\mathrm{L}$ & VL & $\mathrm{L}$ & $\mathrm{L}$ & $\mathrm{VL}$ & VL & $\mathrm{L}$ & $\mathrm{H}$ & $\mathrm{VH}$ & $\mathrm{H}$ \\
\hline TC2 & $\mathrm{VH}$ & $\mathrm{H}$ & $\mathrm{VH}$ & VH & $\mathrm{N}$ & $\mathrm{H}$ & $\mathrm{H}$ & $\mathrm{H}$ & $\mathrm{H}$ & $\mathrm{H}$ & $\mathrm{H}$ & $\mathrm{H}$ & $\mathrm{L}$ & $\mathrm{H}$ & $\mathrm{L}$ & VL & $\mathrm{H}$ \\
\hline TC3 & $\mathrm{VH}$ & $\mathrm{H}$ & $\mathrm{H}$ & $\mathrm{H}$ & $\mathrm{L}$ & $\mathrm{N}$ & $\mathrm{H}$ & $\mathrm{H}$ & $\mathrm{H}$ & $\mathrm{L}$ & VL & $\mathrm{H}$ & $\mathrm{H}$ & $\mathrm{H}$ & $\mathrm{L}$ & $\mathrm{H}$ & $\mathrm{H}$ \\
\hline CL1 & $\mathrm{H}$ & $\mathrm{H}$ & $\mathrm{H}$ & $\mathrm{L}$ & $\mathrm{H}$ & $\mathrm{L}$ & $\mathrm{N}$ & $\mathrm{VH}$ & $\mathrm{H}$ & $\mathrm{H}$ & $\mathrm{H}$ & $\mathrm{VH}$ & $\mathrm{H}$ & $\mathrm{H}$ & $\mathrm{L}$ & $\mathrm{H}$ & $\mathrm{H}$ \\
\hline CL2 & $\mathrm{H}$ & $\mathrm{L}$ & VL & $\mathrm{N}$ & VL & $\mathrm{N}$ & $\mathrm{H}$ & $\mathrm{N}$ & $\mathrm{H}$ & $\mathrm{H}$ & $\mathrm{VH}$ & $\mathrm{H}$ & $\mathrm{L}$ & $\mathrm{L}$ & $\mathrm{H}$ & $\mathrm{L}$ & $\mathrm{L}$ \\
\hline CL3 & $\mathrm{VH}$ & $\mathrm{H}$ & $\mathrm{L}$ & VL & $\mathrm{N}$ & VL & $\mathrm{H}$ & $\mathrm{H}$ & $\mathrm{N}$ & L & $\mathrm{H}$ & $\mathrm{VH}$ & $\mathrm{H}$ & $\mathrm{L}$ & $\mathrm{H}$ & $\mathrm{H}$ & $\mathrm{L}$ \\
\hline RL1 & $\mathrm{H}$ & $\mathrm{L}$ & $\mathrm{L}$ & $\mathrm{H}$ & $\mathrm{H}$ & $\mathrm{H}$ & $\mathrm{L}$ & $\mathrm{L}$ & $\mathrm{H}$ & $\mathrm{N}$ & $\mathrm{H}$ & $\mathrm{L}$ & $\mathrm{H}$ & $\mathrm{L}$ & $\mathrm{H}$ & $\mathrm{H}$ & $\mathrm{L}$ \\
\hline RL2 & $\mathrm{H}$ & $\mathrm{H}$ & $\mathrm{H}$ & VL & $\mathrm{L}$ & $\mathrm{L}$ & $\mathrm{H}$ & $\mathrm{H}$ & VH & $\mathrm{H}$ & $\mathrm{N}$ & $\mathrm{L}$ & $\mathrm{H}$ & $\mathrm{L}$ & $\mathrm{H}$ & $\mathrm{H}$ & $\mathrm{L}$ \\
\hline RL3 & $\mathrm{H}$ & $\mathrm{H}$ & $\mathrm{H}$ & VL & $\mathrm{L}$ & $\mathrm{N}$ & $\mathrm{H}$ & $\mathrm{VH}$ & $\mathrm{H}$ & $\mathrm{L}$ & $\mathrm{VH}$ & $\mathrm{N}$ & $\mathrm{L}$ & $\mathrm{L}$ & $\mathrm{H}$ & $\mathrm{L}$ & $\mathrm{L}$ \\
\hline RL4 & $\mathrm{VH}$ & $\mathrm{L}$ & $\mathrm{L}$ & $\mathrm{H}$ & $\mathrm{N}$ & $\mathrm{N}$ & $\mathrm{H}$ & $\mathrm{VH}$ & $\mathrm{H}$ & VL & $\mathrm{L}$ & $\mathrm{H}$ & $\mathrm{N}$ & $\mathrm{N}$ & VH & $\mathrm{H}$ & $\mathrm{L}$ \\
\hline MG1 & $\mathrm{H}$ & $\mathrm{H}$ & $\mathrm{H}$ & $\mathrm{L}$ & $\mathrm{N}$ & VL & $\mathrm{L}$ & $\mathrm{H}$ & $\mathrm{H}$ & $\mathrm{H}$ & $\mathrm{L}$ & $\mathrm{H}$ & $\mathrm{L}$ & $\mathrm{N}$ & $\mathrm{H}$ & VH & $\mathrm{H}$ \\
\hline MG2 & $\mathrm{VH}$ & $\mathrm{L}$ & $\mathrm{H}$ & $\mathrm{L}$ & $\mathrm{L}$ & $\mathrm{N}$ & $\mathrm{N}$ & $\mathrm{H}$ & $\mathrm{VH}$ & $\mathrm{H}$ & $\mathrm{L}$ & $\mathrm{L}$ & $\mathrm{L}$ & $\mathrm{H}$ & $\mathrm{N}$ & $\mathrm{L}$ & $\mathrm{L}$ \\
\hline MG3 & $\mathrm{H}$ & $\mathrm{H}$ & $\mathrm{L}$ & $\mathrm{L}$ & $\mathrm{H}$ & $\mathrm{L}$ & $\mathrm{L}$ & $\mathrm{H}$ & $\mathrm{L}$ & VL & $\mathrm{H}$ & $\mathrm{L}$ & $\mathrm{H}$ & $\mathrm{L}$ & $\mathrm{H}$ & $\mathrm{N}$ & $\mathrm{L}$ \\
\hline MG4 & $\mathrm{N}$ & $\mathrm{H}$ & $\mathrm{H}$ & $\mathrm{L}$ & $\mathrm{H}$ & $\mathrm{VH}$ & $\mathrm{L}$ & $\mathrm{L}$ & $\mathrm{L}$ & $\mathrm{L}$ & $\mathrm{L}$ & $\mathrm{VH}$ & $\mathrm{VH}$ & $\mathrm{H}$ & $\mathrm{H}$ & $\mathrm{L}$ & $\mathrm{H}$ \\
\hline
\end{tabular}

Table 10. Prominence and cause/effect values

\begin{tabular}{|l|c|c|c|c|}
\hline Barrier & R & C & R + C & R - C \\
\hline FN1 & 4.90 & 5.98 & 10.88 & -1.07 \\
\hline FN2 & 6.05 & 5.02 & 11.07 & 1.03 \\
\hline FN3 & 5.80 & 5.18 & 10.98 & 0.62 \\
\hline TC1 & 4.84 & 4.50 & 9.34 & 0.34 \\
\hline TC2 & 5.63 & 3.99 & 9.61 & 1.64 \\
\hline TC3 & 5.33 & 3.52 & 8.84 & 1.81 \\
\hline CL1 & 5.92 & 5.12 & 11.05 & 0.80 \\
\hline CL2 & 4.41 & 6.09 & 10.50 & -1.69 \\
\hline CL3 & 4.59 & 5.33 & 9.92 & -0.74 \\
\hline RL1 & 5.08 & 4.76 & 9.84 & 0.31 \\
\hline RL2 & 5.18 & 5.48 & 10.66 & -0.30 \\
\hline RL3 & 5.19 & 5.25 & 10.44 & -0.06 \\
\hline RL4 & 4.72 & 5.65 & 10.37 & -0.93 \\
\hline MG1 & 4.82 & 5.02 & 9.83 & -0.20 \\
\hline MG2 & 4.28 & 5.87 & 10.14 & -1.59 \\
\hline MG3 & 4.58 & 5.59 & 10.18 & -1.01 \\
\hline MG4 & 5.33 & 4.30 & 9.64 & 1.03 \\
\hline
\end{tabular}

The barriers with the positive $(\mathrm{R}-\mathrm{C})$ values are known as causal barriers. The barriers TC3, TC2, FN2, MG4 and CL1 are found to be the most important causal barriers to CLSC 
implementation. These barriers should be eliminated in the long term (Cui et al., 2019). The barriers with negative $(\mathrm{R}-\mathrm{C})$ values are known as effect barriers. The analysis reveals RL4, MG3, FN1, MG2 and CL2 to be the major effect barriers. The causal relationships among the barriers are presented in Fig. 3. Though, there exists a number of relationships among the barriers, we depict only those relationships which are above a certain value ' $x$ '. The value of ' $x$ ' is calculated by: $\mu+\sigma$, where $\mu$ denotes average of values of total relation matrix and, and $\sigma$ denotes standard deviation. These values (more than $\mathrm{x}$ ) are given in bold in Total relation matrix (Appendix 4).

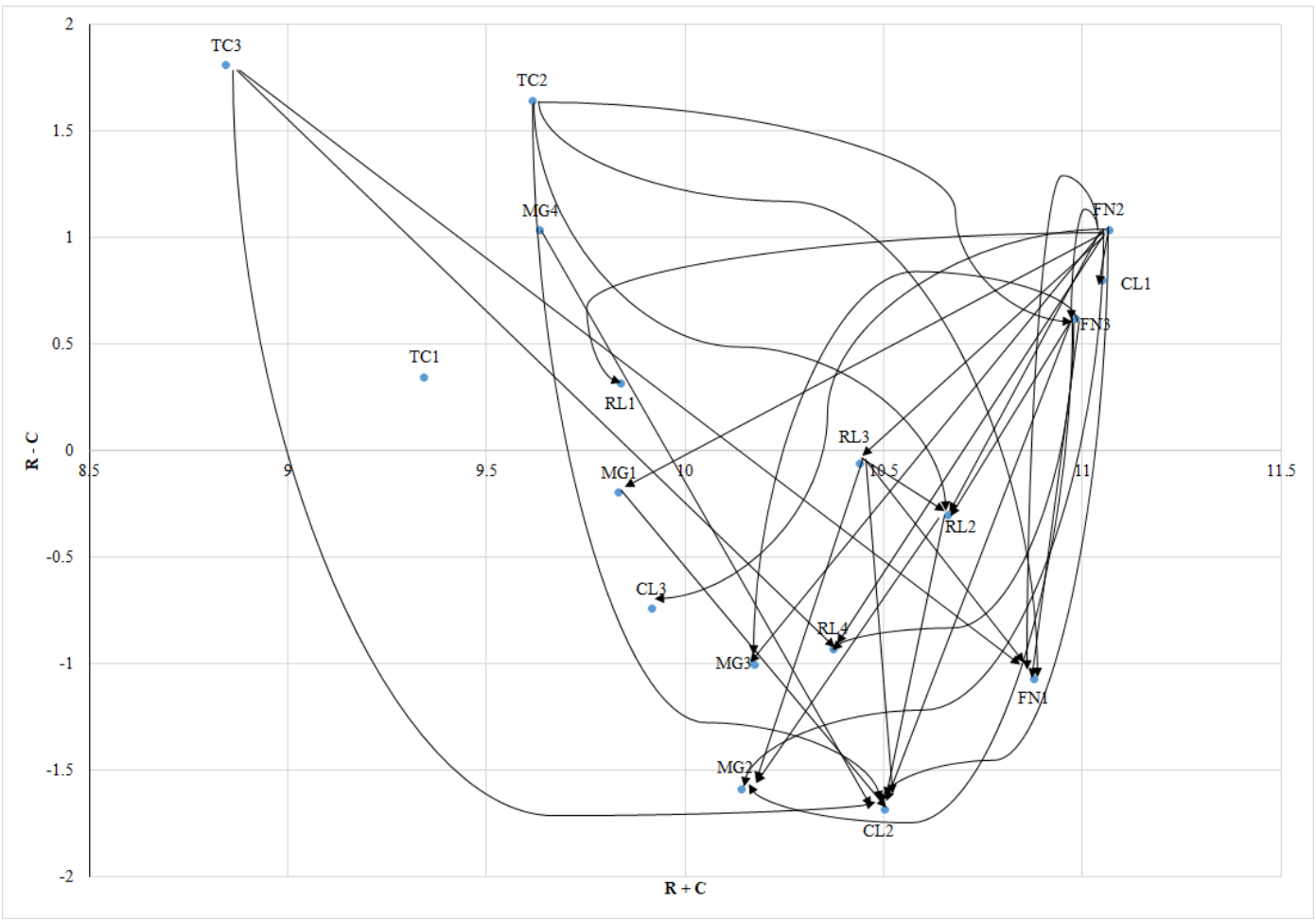

Fig. 3. Causal relationships diagram

\section{Sensitivity analysis}

In MCDM analysis, vagueness of data, inaccuracy and judgements of the experts may affect the results (Moktadir et al., 2019). Further, changes in relative weights can result in change in 
rankings of variables (Mangla et al., 2017). Sensitivity analysis is done to check the robustness of findings (Changes in rankings, and cause and effect groups of barriers). In this study, using AHP, managerial barriers (MG) is ranked as the most important of all categories of barriers. Thus, the weight of managerial barriers is varied from 0.1 to 0.9 , with each increment of 0.1 . The change in weights of other categories of barriers is done simultaneously. The weights of different categories of barriers using sensitivity analysis are shown in Table 11.

As a result of changes in weights of categories of barriers, weights and rankings of sub-barriers are also changed. When managerial barrier is assigned the weights from $0.4-0.9$, MG3 holds the first rank. When the weight is varied from $0.4-0.6$, RL4 has the second rank, MG4 has the third rank and MG2 has the fourth rank. During the variation of the weight from $0.7-0.9$, MG4 gets the second rank and MG2 gets the third rank. Hence, it can be concluded that managerial barriers need to be focused most in the short run for implementation of CLSC. The rankings of sub-barriers using sensitivity analysis are given in Table 12.

Table 11. Weights of category of barriers using sensitivity analysis

\begin{tabular}{|l|c|c|c|c|c|c|c|c|c|c|}
\hline Barriers & Normal & $\mathbf{0 . 1}$ & $\mathbf{0 . 2}$ & $\mathbf{0 . 3}$ & $\mathbf{0 . 4}$ & $\mathbf{0 . 5}$ & $\mathbf{0 . 6}$ & $\mathbf{0 . 7}$ & $\mathbf{0 . 8}$ & $\mathbf{0 . 9}$ \\
\hline FN & 0.0483 & 0.0726 & 0.0645 & 0.0564 & 0.0484 & 0.0403 & 0.0322 & 0.0242 & 0.0161 & 0.0080 \\
\hline TC & 0.0609 & 0.0915 & 0.0813 & 0.0711 & 0.0610 & 0.0508 & 0.0406 & 0.0305 & 0.0203 & 0.0101 \\
\hline CL & 0.1663 & 0.2496 & 0.2219 & 0.1941 & 0.1664 & 0.1387 & 0.1109 & 0.0832 & 0.0554 & 0.0277 \\
\hline RL & 0.3238 & 0.4861 & 0.4321 & 0.3781 & 0.3241 & 0.2701 & 0.2160 & 0.1620 & 0.1080 & 0.0540 \\
\hline MG & 0.4005 & 0.1 & 0.2 & 0.3 & 0.4 & 0.5 & 0.6 & 0.7 & 0.8 & 0.9 \\
\hline Total & 1 & 1 & 1 & 1 & 1 & 1 & 1 & 1 & 1 & 1 \\
\hline
\end{tabular}

Table 12. Ranks of sub-barriers using sensitivity analysis

\begin{tabular}{|l|c|c|c|c|c|c|c|c|c|c|}
\hline Barrier & Normal & $\mathbf{0 . 1}$ & $\mathbf{0 . 2}$ & $\mathbf{0 . 3}$ & $\mathbf{0 . 4}$ & $\mathbf{0 . 5}$ & $\mathbf{0 . 6}$ & $\mathbf{0 . 7}$ & $\mathbf{0 . 8}$ & $\mathbf{0 . 9}$ \\
\hline FN1 & 15 & 13 & 15 & 15 & 15 & 15 & 15 & 15 & 15 & 15 \\
\hline FN2 & 16 & 15 & 16 & 16 & 16 & 16 & 16 & 16 & 16 & 16 \\
\hline FN3 & 13 & 10 & 10 & 12 & 13 & 13 & 13 & 13 & 13 & 13 \\
\hline TC1 & 17 & 16 & 17 & 17 & 17 & 17 & 17 & 17 & 17 & 17 \\
\hline TC2 & 14 & 11 & 13 & 14 & 14 & 14 & 14 & 14 & 14 & 14 \\
\hline
\end{tabular}




\begin{tabular}{|l|c|c|c|c|c|c|c|c|c|c|}
\hline TC3 & 11 & 8 & 9 & 11 & 11 & 12 & 12 & 12 & 12 & 12 \\
\hline CL1 & 6 & 3 & 4 & 4 & 6 & 6 & 7 & 7 & 7 & 7 \\
\hline CL2 & 9 & 6 & 7 & 9 & 9 & 10 & 10 & 10 & 10 & 10 \\
\hline CL3 & 5 & 2 & 3 & 3 & 5 & 5 & 6 & 6 & 6 & 6 \\
\hline RL1 & 10 & 7 & 8 & 10 & 10 & 11 & 11 & 11 & 11 & 11 \\
\hline RL2 & 8 & 5 & 6 & 6 & 8 & 9 & 9 & 9 & 9 & 9 \\
\hline RL3 & 7 & 4 & 5 & 5 & 7 & 7 & 8 & 8 & 8 & 8 \\
\hline RL4 & 2 & 1 & 1 & 1 & 2 & 2 & 2 & 4 & 5 & 5 \\
\hline MG1 & 12 & 17 & 14 & 13 & 12 & 8 & 5 & 5 & 4 & 4 \\
\hline MG2 & 4 & 14 & 12 & 8 & 4 & 4 & 4 & 3 & 3 & 3 \\
\hline MG3 & 1 & 9 & 2 & 2 & 1 & 1 & 1 & 1 & 1 & 1 \\
\hline MG4 & 3 & 12 & 11 & 7 & 3 & 3 & 3 & 2 & 2 & 2 \\
\hline
\end{tabular}

The sensitivity analysis is also performed for the results obtained using grey - DEMATEL. Three experiments (ET1, ET2, ET3) are performed to check the robustness. In ET1, first expert is assigned a weight equal to 0.5 , and other experts are assigned equal weights (0.25). Similarly, other experiments are done by assigning higher weights to other experts. The $(\mathrm{R}+\mathrm{C})$ rankings show that barriers CL1, FN2, FN3 and FN1 have the highest prominence values (Table 13). The ( $\mathrm{R}-\mathrm{C})$ rankings show barriers TC6, TC5, FN2 and MG4 to be causal and RL4, MG3, FN1, MG2 and CL2 to be the effect barriers (Table 13). Thus, the results are relatively robust to expert evaluations and can be used for decision making.

Table 13. Sensitivity analysis (DEMATEL analysis)

\begin{tabular}{|c|c|c|c|c|c|c|c|}
\hline \multicolumn{3}{|c|}{ R + C ranks } & \multicolumn{4}{c|}{ R - C ranks } \\
\hline Equal weights & ET1 & ET2 & ET3 & Equal weights & ET1 & ET2 & ET3 \\
\hline FN2 & FN2 & FN2 & FN2 & TC3 & TC3 & TC3 & TC3 \\
\hline CL1 & FN3 & FN3 & FN3 & TC2 & TC2 & TC2 & TC2 \\
\hline FN3 & FN1 & CL1 & CL1 & FN2 & FN2 & MG4 & FN2 \\
\hline FN1 & CL1 & FN1 & RL2 & MG4 & MG4 & FN2 & MG4 \\
\hline RL2 & RL2 & RL2 & CL2 & CL1 & CL1 & CL1 & CL1 \\
\hline CL2 & CL2 & CL2 & RL4 & FN3 & FN3 & FN3 & FN3 \\
\hline RL3 & RL3 & RL3 & FN1 & TC1 & TC1 & TC1 & TC1 \\
\hline RL4 & RL4 & RL4 & RL3 & RL1 & RL1 & RL1 & RL1 \\
\hline MG3 & MG2 & MG3 & MG3 & RL3 & RL3 & RL3 & RL3 \\
\hline MG2 & MG3 & MG2 & MG2 & MG1 & RL2 & RL2 & MG1 \\
\hline CL3 & CL3 & CL3 & RL1 & RL2 & CL3 & CL3 & CL3 \\
\hline RL1 & MG4 & MG1 & MG1 & CL3 & MG3 & RL4 & RL4 \\
\hline MG1 & RL1 & RL1 & CL3 & RL4 & RL4 & FN1 & MG3 \\
\hline MG4 & MG1 & MG4 & TC2 & MG3 & FN1 & MG3 & FN1 \\
\hline TC2 & TC2 & TC2 & MG4 & FN1 & &
\end{tabular}


This article has been accepted for publication in a future issue of this journal, but has not been fully edited. Content may change prior to final publication. Citation information: DOI10.1109/TEM.2020.2998794, IEEE Transactions on Engineering Management

\begin{tabular}{|c|c|c|c|c|c|c|c|}
\hline TC1 & TC1 & TC1 & TC1 & MG2 & MG2 & MG2 & MG2 \\
\hline TC3 & TC3 & TC3 & TC3 & CL2 & CL2 & CL2 & CL2 \\
\hline
\end{tabular}

\section{Discussion and managerial implications}

This section provides recommendations for managers and policy makers to overcome the barriers. Firstly, we discuss the results from AHP and thereafter results from grey - DEMATEL. From AHP analysis, 'managerial barriers' is found to be the most prominent category of barriers to CLSC implementation. 'Regulatory barriers' and 'Cultural barriers' are found to be the next important categories of barriers. Our result differs from that of Kirchherr et al. (2018), who found cultural barriers to be more prominent in the context of European nations (Hesitant company culture). The possible reason could be that the companies are traditionally operating in a linear system and they are into the state of inertia. They may find it difficult to collaborate with other companies for implementing CLSC. On the other hand, in Indian context, managers are not incentivized or their performance is not mapped by the stakeholders for the extant of CLSC implementation. The possible reason for the lack of incentivization could be no strict regulatory environment in developing countries such as India. In fact, based on a holistic review of CE in China, Su et al. (2013) also identified weak economic incentives and poor enforcement ability of legislation as key barriers for CE implementation. MG3, RL4, MG4 and MG2 (see table 6 for description) are found to be the most prominent sub-barriers. These barriers need to be addressed in the short run for successful implementation of CLSC.

The barrier, "No inventive schemes for managers to use recycled materials" (MG3) holds the first position. Mangla et al. (2018) also found this as to be one of the important barrier to implementing CLSC. Implementation of CLSC involves commitment from leadership and supports from managers, as it involves bringing major changes in an organization (Jayaraman et 
al., 1999). Managers will only be interested to take painstaking efforts if they are provided with some extra benefits. We may invoke the agency theory to explain the reason for the utmost importance this barrier. The CLSC practices may sacrifice the short-term profitability of the company for prospective growth in the future. However, the agents (Managers in the company) are concerned with this inherent risk associated with CLSC implementation. Moreover, this may lead to an agency problem between the principals (stakeholders in our case who demands for CLSC implementation) and the agents. Therefore, incentives need to be provided to managers to align the goals to resolve the agency problem. The top management in an organization may consider this issue and provide managers with extra benefits for their efforts towards the implementation of CLSC.

The barrier, "Financial governmental incentives support the linear economy" (RL4) holds the second position. The result agrees with Zhang et al. (2017) and Mangla et al. (2018), who found lack of government support and lack of preferential tax policies as key barriers to CLSC, respectively. In this regard, policy makers need to provide initial financial support to organizations to implement CLSC practices. This also has implications for Indian government, as to how it can formulate its regulatory framework so as to stimulate adoption of CLSC practices with a long term enduring focus (Sharma et al., 2016; Shi et al., 2019; Bhatia and Srivastava, 2019). The other important barriers are "Lack of required skills by employees" (MG4) and "Higher priority of other issues in supply chain" (MG2). Companies need to build the necessary tactical capabilities and capacities to adopt CLSC practices and gain competitive advantage (Xia et al., 2015). Tactical capabilities can be built by imparting skills to employees through training. Infact, empirical studies in the extant literature also establish the need to inculcate necessary 
This article has been accepted for publication in a future issue of this journal, but has not been fully edited. Content may change prior to final publication. Citation information: DOI10.1109/TEM.2020.2998794, IEEE Transactions on Engineering Management

skills in employees to adopt sustainability practices. An empirical study of Spanish automotive industry by Sarkis et al. (2010) also concludes that training plays an important mediator role for adoption of environmentally oriented reverse logistics practices. Top leadership of firms need to set clear priorities to managers and impart relevant skills to employees.

From DEMATEL analysis, it is found that TC3, TC2, FN2, MG4, CL1, FN3 and TC1 are the important causal barriers and these need to be in addressed in the long run. It can be observed that technological barriers are major barriers in CLSC implementation, which is different from the finding by Kirchherr et al. (2018), who found technological barriers to be least critical in the context of European countries. This is probably due to the reason that firms in developing nations such as India are behind on adoption of technologies in comparison to the developed nations such as European countries, USA, etc. (Castellacci, 2008). On the other hand, the finding that barrier FN2 ("Major upfront investment required for CLSC implementation") is one of the major barrier, agrees with the findings of Abdulrahman et al. (2014), Xia et al. (2015), Rizos et al. (2015) and Kirchherr et al. (2018). This implies that the firms around the world consider 'major upfront costs for implementing CLSC' as one of the major barrier to CLSC implementation.

The barrier, "New challenges to separate the bio-material from the techno-cycle" (TC3) is the most important causal barrier. There are three reasons for it to be biggest barrier in CLSC implementation. Firstly, existing products are not designed to keeping in mind their recycling and reuse. Secondly, separation technologies have limited capabilities to sort out waste streams. Finally, end product user is not educated enough to dump the recyclable and non-recyclable 
waste separately. "Limited availability and quality of recycling material" (TC2) is the second most important causal barrier. Similar finding is obtained by Xia et al. (2015) in the context of remanufacturing of automotive parts in China. To eliminate TC2, policy makers need to develop channels for collecting the used products, so that used products are available in good amount for the further processes. "Lack of required skills by employees" (MG4) is another important causal barrier. The skills and expertise cannot be gained by employees in a short period of time. Thus, as stated earlier, management needs to start now and continuously impart relevant skills to employees. "Lack of awareness" (CL1) is another barrier that will need to be addressed (Wei et al., 2015; Kirchherr et al., 2018). Policy makers and managers should increase awareness among customers about remanufactured products (Bhatia and Srivastava, 2018). "Total cost of product made from recycled materials is often higher" (FN3) and "Low quality of remanufactured products" (TC1) are the other causal barriers. The "Cost" and "Quality" are two important parameters for customers to buy the product. If the product made by recycled material are costly and of low quality, then certainly they act as barriers to CLSC implementation. All in all, business organizations need to make strategies to tackle these short term barriers and long term barriers to successfully implement CLSC.

\section{Conclusions, limitations and future work}

Resource scarcity, deterioration of environment and increased generation of toxic waste has made execution of CLSC practices necessary for firms. However, there are several challenges to implementation of a CLSC. This requires not only the organizations to act but also needs support from government, customers and society. This research identifies key barriers to CLSC implementation, evaluates the prominent barriers, and identifies the causal relationships among 
the barriers. The AHP findings indicate 'Managerial barriers' as the most prominent category of barriers and 'Regulatory barriers' as the second most important category of barriers. The findings from grey - DEMATEL indicate 'technological barriers' to be the important causal barriers. The findings can be useful for organizations that are planning to implement CLSC practices or those in the early stages of CLSC implementation, in emerging economies. The organizations can draft the strategies to eliminate the barriers, for short term and for long term. We also provide implications for managers and policy makers, and suggest recommendations to eradicate the barriers to CLSC implementation.

The study has few limitations. The verification of barriers with the aid of statistical approach such as Structural equation modeling (SEM) is very interesting future research proposition. Future studies can also study the prominent barriers in other industries and compare the results with those obtained from this research. Furthermore, in practical MCDM problems, decision makers tend to use linguistic preference information instead of numerical information. Zhang et al. (2016) proposed a novel linguistic based computational approach by using the extended linguistic hierarchies. Yu et al. (2019) proposed a minimum adjustment-based approach for consensus in MCDM with multi-granular hesitant fuzzy linguistic term sets. Zhang et al. (2019) developed an algorithm to represent a linguistic distribution assessment using a hesitant linguistic distribution. The readers are encouraged to refer the $\mathrm{Yu}$ et al. (2019), Zhang et al. (2019) and Zhang et al. (2016) for detailed discussion.

\section{References}

Abdulrahman, M. D., Gunasekaran, A., \& Subramanian, N. (2014). Critical barriers in implementing reverse logistics in the Chinese manufacturing sectors. International Journal of Production Economics, 147, 460-471. 
Atasu, A., Guide Jr, V.D.R., Van Wassenhove, L.N., 2008. Product reuse economics in closed loop supply chain research. Production and Operations Management 17(5), 483-496.

Bai, C., \& Sarkis, J. (2013). A grey-based DEMATEL model for evaluating business process management critical success factors. International Journal of Production Economics, 146(1), 281-292.

Bhatia, M. S., \& Kumar Srivastava, R. (2019). Antecedents of implementation success in closedloop supply chain: an empirical investigation. International Journal of Production Research, 57(23), 7344-7360.

Bhatia, M. S., Jakhar, S. K., Mangla, S. K., \& Gangwani, K. K. (2020). Critical factors to environment management in a closed loop supply chain. Journal of Cleaner Production, 255, 120239.

Bhatia, M. S., Srivastava, R.K., 2018. Analysis of external barriers to remanufacturing using grey-DEMATEL approach: An Indian perspective. Resources, Conservation and Recycling 136, 79-87.

Bouzon, M., Govindan, K., Rodriguez, C.M.T., Campos, L.M., 2016. Identification and analysis of reverse logistics barriers using fuzzy Delphi method and AHP. Resources, Conservation and Recycling 108, 182-197.

Castellacci, F. (2008). Technological paradigms, regimes and trajectories: Manufacturing and service industries in a new taxonomy of sectoral patterns of innovation. Research Policy, 37(67), 978-994.

Cui, L., Chan, H. K., Zhou, Y., Dai, J., \& Lim, J. J. (2019). Exploring critical factors of green business failure based on Grey-Decision Making Trial and Evaluation Laboratory (DEMATEL). Journal of Business Research, 98, 450-461.

Dang, S., Chu, L., 2016. Evaluation framework and verification for sustainable container management as reusable packaging. Journal of Business Research 69(5), 1949-1955.

Darbari, J. D., Kannan, D., Agarwal, V., \& Jha, P. C. (2019). Fuzzy criteria programming approach for optimising the TBL performance of closed loop supply chain network design problem. Annals of Operations Research, 273(1-2), 693-738.

de Man, R., Friege, H., 2016. Circular Economy: European Policy on Shaky Ground. Waste Management \& Research 34 (2), 93-95

Deng, J.L. 1989. “Introduction to grey system theory." The Journal of Grey System 1(1): 1-24. 
This article has been accepted for publication in a future issue of this journal, but has not been fully edited. Content may change prior to final publication. Citation information: DOI10.1109/TEM.2020.2998794, IEEE Transactions on Engineering Management

Dervojeda, K., Verzij1, D., Rouwmaat, E., Probst, L., Frideres., L., 2014. Clean technologies circular supply chains. EU report, 248-274.

Diabat, A., Abdallah, T., Al-Refaie, A., Svetinovic, D., \& Govindan, K. (2013). Strategic closedloop facility location problem with carbon market trading. IEEE Transactions on engineering Management, 60(2), 398-408.

Dora, M., Bhatia, M. S., Gallear, D., 2016. Supply Chain in a Circular Economy: A Multidimensional Agenda. Online Available at: http://bura.brunel.ac.uk/handle/2438/13002

Dou, Y., Q. Zhu, and J. Sarkis .2014. "Evaluating green supplier development programs with a grey-analytical network process-based methodology." European Journal of Operational Research 233(2): 420-431

Duman, G. M., El-Sayed, A., Kongar, E., \& Gupta, S. M. (2019). An intelligent multiattribute group decision-making approach with preference elicitation for performance evaluation. IEEE Transactions on Engineering Management.

Dwivedi, G., Srivastava, R. K., \& Srivastava, S. K. (2018). A generalised fuzzy TOPSIS with improved closeness coefficient. Expert Systems with Applications, 96, 185-195.

Easwaran, G., Üster. H., 2010. A closed-loop supply chain network design problem with integrated forward and reverse channel decisions. IIE transactions 42(11), 779-792.

Ellen MacArthur Foundation, 2013. Towards a circular economy: economic and business rationale for an accelerated transition. Retrieved July 30, 2018 from http://www.ellenmacarthurfoundation.org/business/reports.

Ellen MacArthur Foundation, 2016. Circular Economy in India: Rethinking growth for long-term $\begin{array}{llllll}\text { prosperity. } & \text { Retrieved } & \text { July } & 30, & 2018 & \text { from }\end{array}$ https://www.ellenmacarthurfoundation.org/assets/downloads/publications/Circular-economy-inIndia_5-Dec_2016.pdf

FICCI, 2018. Accelerating India's Circular Economy Shift A Half-Trillion USD Opportunity Future-proofing growth in a resource-scarce world. Retrieved July 30, 2018 from http://ficci.in/spdocument/22977/FICCI-Circular-Economy.pdf

Fontela, E., Gabus, A., 1974. The DEMATEL, Innovative Methods. Research Report 2: Structural Analysis of the World Problematique. Battelle Institute, Geneva. 
This article has been accepted for publication in a future issue of this journal, but has not been fully edited. Content may change prior to final publication. Citation information: DOI10.1109/TEM.2020.2998794, IEEE Transactions on Engineering Management

Gandhi, S., Mangla, S. K., Kumar, P., \& Kumar, D. (2016). A combined approach using AHP and DEMATEL for evaluating success factors in implementation of green supply chain management in Indian manufacturing industries. International Journal of Logistics Research and Applications, 19(6), 537-561.

Garg, K., Kannan, D., Diabat, A., Jha. P. C., 2015. A multi-criteria optimization approach to manage environmental issues in closed loop supply chain network design. Journal of Cleaner Production 100, 297-314.

Geng, Y., Fu, J., Sarkis, J., Xue, B., 2012. Towards a national circular economy indicator system in China: an evaluation and critical analysis. Journal of Cleaner Production 23(1), 216-224.

Genovese, A., Acquaye, A.A., Figueroa, A, Koh, S.L., 2017. Sustainable supply chain management and the transition towards a circular economy: Evidence and some applications. Omega 66, 344-357.

Ghisellini, P., Cialani, C., Ulgiati, S., 2016. A review on circular economy: the expected transition to a balanced interplay of environmental and economic systems. Journal of Cleaner production 114, 11-32.

Gölcük, İ., \& Baykasoğlu, A. (2016). An analysis of DEMATEL approaches for criteria interaction handling within ANP. Expert Systems with Applications, 46, 346-366.

Govindan, K., Hasanagic, M., 2018. A systematic review on drivers, barriers, and practices towards circular economy: a supply chain perspective. International Journal of Production Research 56(1-2), 278-311.

Govindan, K., Kaliyan, M., Kannan, D., Haq, A.N., 2014. Barriers analysis for green supply chain management implementation in Indian industries using analytic hierarchy process. International Journal of Production Economics 147, 555-568.

Govindan, K., Khodaverdi, R., Vafadarnikjoo, A., 2015b. Intuitionistic fuzzy based DEMATEL method for developing green practices and performances in a green supply chain. Expert Systems with Applications 42(20), 7207-7220.

Govindan, K., Soleimani, H., Kannan, D., 2015a. Reverse logistics and closed-loop supply chain: A comprehensive review to explore the future. European Journal of Operational Research 240(3), 603-626.

Guide Jr, V. D. R., Van Wassenhove, L.N., 2009. OR FORUM-The evolution of closed-loop supply chain research. Operations research 57(1), 10-18. 
Guide Jr., V. D. R., Harrison, T.P., Van Wassenhove, L.N., 2003. The challenge of closed-loop supply chains. Interfaces 33(6), 3-6.

Harputlugil, T. I. M. U. C. I. N., Prins, M. A. T. T. H. I. J. S., Gültekin, A. T., \& Topçu, Y. I. (2011). Conceptual framework for potential implementations of multi criteria decision making (MCDM) methods for design quality assessment.

Hong, I. H., Ke, J.S., 2011. Determining advanced recycling fees and subsidies in "E-scrap" reverse supply chains. Journal of environmental management 92(6), 1495-1502.

Hotten, R (2015, December 10). Volkswagen: The scandal explained. BBC News. Retrieved from http://www.bbc.com/news/business-34324772

Huang, Y. S., Lin, C. J., \& Fang, C. C. (2019). A Study on Recycle Schedules for Trade-In Rebates With Consideration of Product Life Cycle. IEEE Transactions on Engineering Management, 66(3), 475-490.

IBEF. 2019. "Automobile Industry in India. "https://www.ibef.org/industry/indiaautomobiles.aspx (Accessed: 20th January, 2020)

Ilgin, M. A., Gupta, S.M., 2010. Environmentally conscious manufacturing and product recovery (ECMPRO): A review of the state of the art. Journal of environmental management 91(3), 563591.

Ishizaka, A., Labib, A., 2011. Review of the main developments in the analytic hierarchy process. Expert systems with applications 38(11), 14336-14345.

Jayaraman, V., 2006. Production planning for closed-loop supply chains with product recovery and reuse: an analytical approach. International Journal of Production Research 44(5), 981-998.

Jayaraman, V., Guide Jr, V.D.R., Srivastava, R., 1999. A closed-loop logistics model for remanufacturing. Journal of the Operational Research Society 50(5), 497-508

Jeng, D. J. F., Huang, K. H., 2015. Strategic project portfolio selection for national research institutes. Journal of Business Research 68(11), 2305-2311.

Kadambala, D. K., Subramanian, N., Tiwari, M.K., Abdulrahman, M., Liu, C., 2017. Closed loop supply chain networks: Designs for energy and time value efficiency. International Journal of Production Economics 183, 382-393.

Kannan, G., Sasikumar, P., Devika, K., 2010. A genetic algorithm approach for solving a closed loop supply chain model: A case of battery recycling. Applied Mathematical Modelling 34(3), $655-670$. 
Kenne, J.P., Dejax, P., Gharbi, A., 2012. Production planning of a hybrid manufacturingremanufacturing system under uncertainty within a closed-loop supply chain. International Journal of Production Economics 135(1), 81-93.

Kirchherr, J., Piscicelli, L., Bour, R., Kostense-Smit, E., Muller, J., Huibrechtse-Truijens, A., Hekkert, M., 2018. Barriers to the Circular Economy: Evidence From the European Union (EU). Ecological Economics 150, 264-272.

Kok, L., Wurpel, G., Ten Wolde, A., 2013. Unleashing the power of the circular economy. Report by IMSA Amsterdam for Circle Economy.

Krikke, H., Bloemhof-Ruwaard, J., Van Wassenhove, L.N., 2003. Concurrent product and closed-loop supply chain design with an application to refrigerators. International Journal of Production Research 41(16), 3689-3719.

Lee, J. E., Gen, M., Rhee, K.G., 2009. Network model and optimization of reverse logistics by hybrid genetic algorithm. Computers \& Industrial Engineering 56(3), 951-964.

Li, J., Yu, K., 2011. A study on legislative and policy tools for promoting the circular economic model for waste management in China. Journal of Material Cycles and Waste Management 13, 103-112.

Liu, Y., Bai, Y., 2014. An exploration of firms' awareness and behavior of developing circular economy: An empirical research in China. Resources, Conservation and Recycling 87, 145-152.

Luthra, S., Mangla, S. K., Shankar, R., Prakash Garg, C., \& Jakhar, S. (2018). Modelling critical success factors for sustainability initiatives in supply chains in Indian context using GreyDEMATEL. Production Planning \& Control, 29(9), 705-728.

Luthra, S., Mangla, S.K., Xu, L., Diabat, A., 2016. Using AHP to evaluate barriers in adopting sustainable consumption and production initiatives in a supply chain. International Journal of Production Economics 181, 342-349.

Madaan, J., Mangla, S., 2015. Decision modeling approach for eco-driven flexible green supply chain. In Systemic flexibility and business agility (pp. 343-364). Springer India. http://dx.doi.org/10.1007/978-81-322-2151-7_21.

Mangla, S. K., Govindan, K., Luthra, S., 2016. Critical success factors for reverse logistics in Indian industries: a structural model. Journal of cleaner production 129, 608-621. 
Mangla, S. K., Govindan, K., Luthra, S., 2017. Prioritizing the barriers to achieve sustainable consumption and production trends in supply chains using fuzzy Analytical Hierarchy Process. Journal of Cleaner Production 151, 509-525.

Mangla, S. K., Luthra, S., Mishra, N., Singh, A., Rana, N.P., Dora, M., Dwivedi, Y., 2018. Barriers to effective circular supply chain management in a developing country context. Production Planning \& Control 29(6), 551-569.

Mathew, M., Chakrabortty, R. K., \& Ryan, M. J. (2020). Selection of an Optimal Maintenance Strategy Under Uncertain Conditions: An Interval Type-2 Fuzzy AHP-TOPSIS Method. IEEE Transactions on Engineering Management.

Mathiyazhagan, K., Govindan, K., Noorul Haq, A., 2014. Pressure analysis for green supply chain management implementation in Indian industries using analytic hierarchy process. International Journal of Production Research 52(1), 188-202.

Metta, H., \& Badurdeen, F. (2012). Integrating sustainable product and supply chain design: modeling issues and challenges. IEEE Transactions on Engineering Management, 60(2), 438446.

Moktadir, M. A., Ali, S. M., Paul, S. K., \& Shukla, N. (2019). Barriers to big data analytics in manufacturing supply chains: A case study from Bangladesh. Computers \& Industrial Engineering, 128, 1063-1075.

Mudgal, R. K., Shankar, R., Talib, P., Raj, T., 2010. Modelling the barriers of green supply chain practices: an Indian perspective. International Journal of Logistics Systems and Management 7(1), 81-107.

Olugu, E. U., Wong, K.Y., 2012. An expert fuzzy rule-based system for closed-loop supply chain performance assessment in the automotive industry. Expert Systems with Applications 39(1), 375-384.

Östlin, J., Sundin, E., Björkman, M., 2008. Importance of closed-loop supply chain relationships for product remanufacturing. International Journal of Production Economics 115(2), 336-348.

Özceylan, E., Paksoy, T., 2013. A mixed integer programming model for a closed-loop supplychain network. International Journal of Production Research 51(3), 718-734.

Patil, S. K., Kant, R., 2014. Ranking the barriers of knowledge management adoption in supply chain using fuzzy AHP method. International Journal of Business Innovation and Research 8(1), 52-75. 
Pishvaee, M. S., Torabi, S.A., 2010. A possibilistic programming approach for closed-loop supply chain network design under uncertainty. Fuzzy sets and systems, 161(20), 2668-2683.

Rademaekers, K., Asaad, S.S.Z., Berg, J., 2011. Study on the Competitiveness of the European Companies and Resource Efficiency. ECORYS, Teknologisk Institut, Cambridge Econometrics, CES info and Idea Consult. Study prepared for the European Commission, DG Enterprise and Industry.

Rahman, S., Ahsan, K., Yang, L., \& Odgers, J. (2019). An investigation into critical challenges for multinational third-party logistics providers operating in China. Journal of Business Research, 103, 607-619.

Raz, G., Ovchinnikov, A., \& Blass, V. (2017). Economic, environmental, and social impact of remanufacturing in a competitive setting. IEEE Transactions on Engineering Management, 64(4), 476-490.

Rizos, V., Behrens, A., Kafyeke, T., Hirschnitz-Garbers, M., Ioannou, A., 2015. The circular economy: Barriers and opportunities for SMEs. Available at: http://www.greengrowthknowledge.org/sites/default/files/downloads/resource/GreenEconet_CE PS_SMEs_Circular_Economy.pdf

Saaty, T.L., 1980. The Analytic Hierarchy Process. McGraw-Hill International, New York, NY Sarkis, J., Gonzalez-Torre, P., Adenso-Diaz, B., 2010. Stakeholder pressure and the adoption of environmental practices: The mediating effect of training. Journal of Operations Management 28(2), 163-176.

Savaskan, R.C., Bhattacharya, S., Van Wassenhove, L.N., 2004. Closed-loop supply chain models with product remanufacturing. Management science 50(2), 239-252.

Shahbazi, S., Wiktorsson, M., Kurdve, M., Jönsson, C., Bjelkemyr, M., 2016. Material efficiency in manufacturing: Swedish evidence on potential, barriers and strategies. Journal of Cleaner Production 127, 438-450.

Sharma, V., Garg, S. K., \& Sharma, P. B. (2016). Identification of major drivers and roadblocks for remanufacturing in India. Journal of Cleaner Production, 112, 1882-1892.

Shi, H., Peng, S.Z., Liu, Y., Zhong, P., 2008. Barriers to the implementation of cleaner production in Chinese SMEs: government, industry and expert stakeholders' perspectives. Journal of Cleaner Production 16(7), 842-852. 
This article has been accepted for publication in a future issue of this journal, but has not been fully edited. Content may change prior to final publication. Citation information: DOI10.1109/TEM.2020.2998794, IEEE Transactions on Engineering Management

Shi, J., Zhou, J., \& Zhu, Q. (2019). Barriers of a closed-loop cartridge remanufacturing supply chain for urban waste recovery governance in China. Journal of cleaner production, 212, 15441553.

Singh, S., \& Misra, S. C. (2019). Exploring the Challenges for Adopting the Cloud PLM in Manufacturing Organizations. IEEE Transactions on Engineering Management.

Singh, S., Misra, S. C., \& Kumar, S. (2019). Critical barriers to PLM institutionalization in manufacturing organizations. IEEE Transactions on Engineering Management.

Su, B., Heshmati, A., Geng, Y., \& Yu, X. (2013). A review of the circular economy in China: moving from rhetoric to implementation. Journal of cleaner production, 42, 215-227.

Thierry, M., Salomon, M., Van Nunen, J., Van Wassenhove, L.N., 1995. Strategic issues in product recovery management. California management review 37(2), 114-136.

Wang, H. F., Huang, Y.S., 2013. A two-stage robust programming approach to demand-driven disassembly planning for a closed-loop supply chain system. International Journal of Production Research 51(8), 2414-2432.

Weelden, E. V., Mugge, R., Bakker, C., 2016. Paving the Way towards Circular Consumption: Exploring Consumer Acceptance of Refurbished Mobile Phones in the Dutch Market. Journal of Cleaner Production 113, 743-754

World Economic Forum, 2018. Circular Economy in Cities Evolving the model for a sustainable urban future, White Paper, REF 260218-00034436, www.weforum.org.

Wei, S., Cheng, D., Sundin, E., \& Tang, O. (2015). Motives and barriers of the remanufacturing industry in China. Journal of Cleaner Production, 94, 340-351.

Wu, H. H., \& Tsai, Y. N. (2012). An integrated approach of AHP and DEMATEL methods in evaluating the criteria of auto spare parts industry. International Journal of Systems Science, 43(11), 2114-2124.

Xia, X., Govindan, K., \& Zhu, Q. (2015). Analyzing internal barriers for automotive parts remanufacturers in China using grey-DEMATEL approach. Journal of Cleaner Production, 87, 811-825.

Yadav, G., Desai, T.N., 2017. A fuzzy AHP approach to prioritize the barriers of integrated Lean Six Sigma. International Journal of Quality \& Reliability Management 34(8), 1167-1185. 
Yu, W., Zhang, Z., \& Zhong, Q. (2019). Consensus reaching for MAGDM with multi-granular hesitant fuzzy linguistic term sets: a minimum adjustment-based approach. Annals of Operations Research, 1-24.

Zhang, Z., Guo, C., \& Martínez, L. (2016). Managing multigranular linguistic distribution assessments in large-scale multiattribute group decision making. IEEE Transactions on Systems, Man, and Cybernetics: Systems, 47(11), 3063-3076.

Zhang, Z., Yu, W., Martinez, L., \& Gao, Y. (2019). Managing Multigranular Unbalanced Hesitant Fuzzy Linguistic Information in Multiattribute Large-Scale Group Decision Making: A Linguistic Distribution-Based Approach. IEEE Transactions on Fuzzy Systems.

Zhang, J. H., Yang, B., \& Chen, M. (2017). Challenges of the development for automotive parts remanufacturing in China. Journal of Cleaner Production, 140, 1087-1094.

Zhu, Q., Sarkis, J., Lai, K.H., 2014. Supply chain-based barriers for truck-engine remanufacturing in China. Transportation Research Part E: Logistics and Transportation Review 68, 103-117.

\section{Appendix 1: AHP method}

Step 1. Problem formulation: This step comprises identifying barriers to CLSC implementation from literature review and input of industrial experts.

Step 2. Pairwise comparisons of barriers: This step involves pairwise comparisons between barriers using the judgement of industry experts. The comparisons between the barriers are done using the Saaty's scale, given in Table 3.

Step 3. Computation of relative importance weights: This step involves calculation of eigen values and eigen vectors. The relative weights of the factors involved in the study are then calculated using eigen values and eigen vectors.

Step 4. Evaluation of consistency ratio: Finally, evaluations (pairwise comparisons between criteria) made by the decision makers are checked for consistency.

\section{Appendix 2: Grey - DEMATEL method}

Step 1. Direct relation matrix " $D$ ": It represents influence levels between the finalized barriers. It is represented as follows: 
$\mathrm{D}=\left[\begin{array}{ccccccc}0 & d_{12} & d_{13} & \cdots & \cdots & d_{1(n-1)} & d_{1 n} \\ d_{21} & 0 & d_{23} & \cdots & \cdots & d_{2(n-1)} & d_{2 n} \\ \cdots & \cdots & \cdots & \cdots & \cdots & \cdots & \cdots \\ \cdots & \cdots & \cdots & \cdots & \cdots & \cdots & \cdots \\ \cdots & \cdots & \cdots & \cdots & \cdots & \cdots & \cdots \\ d_{(n-1) 1} & d_{(n-1) 2} & d_{(n-1) 3} & d_{(n-1) 4} & \cdots & 0 & d_{(n-1) n} \\ d_{n 1} & d_{n 2} & \cdots & \cdots & \cdots & d_{n(n-1)} & 0\end{array}\right]$

Step 2. Normalization of "D": CFCS (Converting fuzzy data into crisp scores) method is used for converting grey numbers to crisp numbers (Dou et al., 2014). This is explained in detail in Section 3.1.2.

Step 3: Normalized direct-relation matrix "N"

$\mathrm{M}=$ ; M: normalization factor

$$
\max _{1 \leq i \leq n} \sum_{j=1}^{n} d_{i j}
$$

$\mathrm{N}=\mathrm{M} * \mathrm{D}$

Step 4: Total relation matrix "T"

$\mathrm{T}=\mathrm{N}(\mathrm{I}-\mathrm{N})^{-1} ;$ I: Identity matrix

Step 5: Calculation of sum of rows and sum of columns of " $\mathrm{T}$ "

$$
\begin{aligned}
& \mathrm{R}=\left[\sum_{j=1}^{j=n} m_{i j}\right]_{n \times 1} ; \mathrm{R}: \text { sum of rows of "T" } \\
& \mathrm{C}=\left[\sum_{i=1}^{i=n} m_{i j}\right]_{1 \times n}^{\prime} ; \mathrm{C}: \text { sum of columns of " } \mathrm{T} "
\end{aligned}
$$

Step 6: Causal diagram

In causal diagram, $\left(R_{i}+C i\right)$ and $\left(R_{i}-C_{i}\right)$ values are plotted on horizontal and vertical axis, respectively.

\section{Appendix 3: Grey linguistic scale for direct relation matrix}

\begin{tabular}{|l|c|}
\hline Linguistic assessment & Grey number \\
\hline No influence (N) & $(0,0)$ \\
\hline Very low influence (VL) & $(0,0.25)$ \\
\hline Low influence (L) & $(0.25,0.50)$ \\
\hline High influence (H) & $(0.50,0.75)$ \\
\hline Very High influence (VH) & $(0.75,1)$ \\
\hline
\end{tabular}


This article has been accepted for publication in a future issue of this journal, but has not been fully edited. Content may change prior to final publication. Citation information: DOI10.1109/TEM.2020.2998794, IEEE Transactions on Engineering Management

\section{Appendix 4: Total relation matrix}

\begin{tabular}{|c|c|c|c|c|c|c|c|c|c|c|c|c|c|c|c|c|c|}
\hline & FN1 & FN2 & FN3 & TC1 & TC2 & TC3 & CL1 & CL2 & CL3 & RL1 & RL2 & RL3 & RL4 & MG1 & MG2 & MG3 & MG4 \\
\hline FN1 & 0.29 & 0.31 & 0.31 & 0.25 & 0.23 & 0.23 & 0.27 & 0.34 & 0.28 & 0.26 & 0.29 & 0.31 & 0.35 & 0.29 & 0.32 & 0.32 & 0.25 \\
\hline FN2 & 0.42 & 0.30 & 0.37 & 0.33 & 0.31 & 0.25 & 0.36 & 0.40 & 0.36 & 0.36 & \begin{tabular}{|c|}
0.38 \\
\end{tabular} & 0.37 & 0.41 & 0.36 & 0.40 & $\begin{array}{l}0.39 \\
\end{array}$ & 0.30 \\
\hline FN3 & 0.41 & 0.33 & 0.29 & 0.33 & 0.30 & 0.27 & 0.33 & 0.41 & 0.34 & 0.31 & 0.36 & 0.34 & 0.38 & 0.35 & 0.41 & 0.36 & 0.29 \\
\hline TC1 & 0.32 & 0.28 & 0.32 & 0.22 & 0.25 & 0.22 & 0.29 & 0.32 & 0.29 & 0.27 & 0.30 & 0.27 & 0.30 & 0.28 & 0.33 & 0.33 & 0.27 \\
\hline TC2 & 0.39 & 0.33 & 0.36 & 0.33 & 0.22 & 0.26 & 0.34 & 0.39 & 0.34 & 0.32 & 0.37 & 0.34 & 0.35 & 0.32 & 0.34 & 0.35 & 0.28 \\
\hline TC3 & 0.39 & 0.32 & 0.33 & 0.29 & 0.25 & 0.18 & 0.32 & 0.36 & 0.32 & 0.28 & 0.31 & 0.32 & 0.36 & 0.31 & 0.35 & 0.35 & 0.28 \\
\hline CL1 & 0.39 & 0.35 & 0.34 & 0.29 & 0.27 & 0.24 & 0.30 & 0.43 & 0.37 & 0.34 & 0.38 & 0.39 & 0.40 & 0.34 & 0.40 & 0.39 & 0.32 \\
\hline CL2 & 0.30 & 0.25 & 0.25 & 0.19 & 0.18 & 0.15 & 0.28 & 0.27 & 0.29 & 0.27 & 0.32 & 0.30 & 0.29 & 0.26 & 0.32 & 0.28 & 0.22 \\
\hline CL3 & 0.33 & 0.27 & 0.26 & 0.22 & 0.18 & 0.17 & 0.29 & 0.34 & 0.24 & 0.26 & 0.30 & 0.31 & 0.30 & 0.27 & 0.32 & 0.30 & 0.23 \\
\hline RL1 & 0.34 & 0.28 & 0.29 & 0.28 & 0.27 & 0.24 & 0.30 & 0.34 & 0.33 & 0.24 & 0.33 & 0.31 & 0.33 & 0.29 & 0.34 & 0.33 & 0.24 \\
\hline RL2 & 0.35 & 0.30 & 0.30 & 0.25 & 0.24 & 0.21 & 0.32 & 0.38 & 0.34 & 0.30 & 0.28 & 0.32 & 0.35 & 0.30 & 0.36 & 0.34 & 0.24 \\
\hline RL3 & 0.37 & 0.30 & 0.32 & 0.25 & 0.24 & 0.18 & 0.32 & 0.39 & 0.33 & 0.29 & 0.36 & 0.27 & 0.34 & 0.30 & 0.37 & 0.32 & 0.24 \\
\hline RL4 & 0.35 & 0.27 & 0.29 & 0.26 & 0.18 & 0.16 & 0.29 & 0.34 & 0.30 & 0.24 & 0.30 & 0.31 & 0.26 & 0.26 & 0.34 & 0.33 & 0.24 \\
\hline MG1 & 0.33 & 0.28 & 0.30 & 0.24 & 0.20 & 0.18 & 0.29 & 0.36 & 0.31 & 0.27 & 0.30 & 0.29 & 0.30 & 0.24 & 0.34 & 0.34 & 0.26 \\
\hline MG2 & 0.31 & 0.26 & 0.26 & 0.23 & 0.18 & 0.15 & 0.25 & 0.31 & 0.28 & 0.25 & 0.27 & 0.25 & 0.28 & 0.27 & 0.25 & 0.28 & 0.21 \\
\hline MG3 & 0.32 & 0.27 & 0.27 & 0.23 & 0.22 & 0.19 & 0.27 & 0.34 & 0.27 & 0.24 & 0.30 & 0.27 & 0.32 & 0.28 & 0.33 & 0.25 & 0.22 \\
\hline MG4 & 0.37 & 0.30 & 0.33 & 0.32 & 0.26 & 0.26 & 0.31 & 0.38 & 0.34 & 0.28 & 0.33 & 0.30 & 0.33 & 0.32 & 0.35 & 0.35 & 0.23 \\
\hline
\end{tabular}

